\title{
Questões de gênero em estudos comparativos de imigração: mulheres judias em São Paulo e em Nova York*
}

\author{
Ethel V. Kosminsky**
}

\begin{abstract}
Resumo
Este artigo discute as relações de gênero vividas por mulheres imigrantes judias, procedentes da Europa Oriental, que se fixaram em São Paulo e em Nova York, e por suas filhas, nascidas nessas cidades, apontando a importância das categorias gênero e geração nos estudos comparativos de imigração.
\end{abstract}

Palavras-chave: Gênero, Imigração, Geração.

\footnotetext{
* Recebido para publicação em fevereiro de 2004, aceito em maio de 2004. Uma versão preliminar deste trabalho foi apresentada no 27. Encontro Anual da ANPOCS, no GT Migrações Internacionais, Caxambu, outubro de 2003. Agradeço à FAPESP e ao CNPq pelo financiamento da pesquisa, que possibilitou a elaboração deste artigo. Sou grata aos(às) pareceristas pelas suas sugestões, incorporadas na medida do possível, e aos Profs. Giralda Seyferth, Nancy Rozenchan, Geraldo Romanelli e Claude Lépine por seus comentários.

** Professora da UNESP, Marília-SP, Brasil e pesquisadora do CNPq. ethelkos@uol.com.br
}

cadernos pagu (23), julho-dezembro de 2004, pp.279-328. 
Gênero em estudos comparativos de imigração

Gender Issues in Comparative Studies of Immigration: Jewish Women in São Paulo and in New York

\begin{abstract}
This article discusses the Eastern European Jewish immigrants' women gender relationships, who settled in São Paulo and in New York, and their daughters' experiences, showing how important gender and generation categories are for the comparatives studies of international migration.
\end{abstract}

Key Words: Gender, Immigration, Generation. 
Ethel V. Kosminsky

\section{A categoria gênero na pesquisa com mulheres imigrantes judias}

A comparação de imigrantes de uma mesma origem que se fixaram em duas diferentes sociedades permite verificar a plasticidade do processo de adaptação do imigrante em toda a sua riqueza e variedade pelo levantamento das semelhanças e diferenças entre as sociedades receptoras. Trabalharei neste artigo com a possível existência de um padrão de reformulação das relações de gênero ${ }^{1}$ em um grupo étnico, o grupo de judeus imigrantes procedentes da Europa Oriental, que vivenciou o processo de adaptação ${ }^{2}$ à sociedade ocidental, em dois países distintos, o Brasil e os Estados Unidos, tendo se estabelecido na cidade de São Paulo, entre os anos 1911 e 1948, e na cidade de Nova York, no período compreendido entre os anos 1902 e $1922^{3}$

\footnotetext{
1 A categoria gênero é necessária à compreensão dos fenômenos sociais, ao lado das categorias etnia, classe social e geração. O relacionamento entre gênero e as categorias sociais deve ser analisado, levando-se em consideração que todas essas divisões sociais compreendem estruturas de poder. THORNE, B. Feminism and the family: two decades of thought. In: THORNE, B.; YALOM, M. (orgs.) Rethinking the Family. Some Feminist Questions. Boston, Northeastern University Press, 1992, pp.3-30.

2 Emprego a palavra adaptação como um conceito aberto, no sentido usado por Herbert Gans, "enfatizando aspectos positivos e negativos, incluindo tentativas de impedir a aculturação, que alguns vêem como positivas e outros como negativas. Também trato os processos de adaptação e todos os seus conflitos como diretamente afetados por fatores macro-econômicos e macro-sociológicos que têm um impacto nos imigrantes; esses processos e conflitos são por sua própria natureza diferentes para diferentes imigrantes". GANS, Herbert J. Filling in Some Holes: Six Areas of Needed Immigration Research. In: FONER, N.; Rumbaut, R.G. e Gold, S.J. (orgs.) Immigration Research for a New Century. Multidisciplinary Perspectives. New York, Russel Sage Foundation, 2000, pp.76-89.

${ }^{3}$ O processo imigratório de judeus da Europa Oriental para os Estados Unidos é mais antigo e contou com um fluxo muito maior de pessoas do que para o Brasil. Estima-se que, entre 1881 e 1928, 2.414 .989 pessoas imigraram para os Estados Unidos, tendo a maioria se fixado na cidade de Nova York. GolD, Steven J.
} 
Gênero em estudos comparativos de imigração

As metrópoles de Nova York e de São Paulo foram escolhidas como locais da pesquisa em razão de concentrarem o maior número de descendentes de imigrantes judeus. Considerando o período definido, coletamos os relatos das filhas dos imigrantes, pois teria sido impossível ter acesso às histórias de vida da própria geração imigrante. Embora as filhas dos imigrantes não tenham compartilhado das experiências de vida dos seus pais, elas carregam consigo essas memórias, as recordações daquilo que observaram, do que ouviram e do que sentiram.

Algumas das informações apresentadas foram coletadas na primeira fase da pesquisa, quando buscamos cobrir uma lacuna dos estudos migratórios, resgatando a perspectiva da mulher, pouco utilizada nas pesquisas realizadas no Brasil. ${ }^{4}$ Ao tratarmos

From the Jazz Singer to What a Country! A Comparison of Jewish Migration to the United States, 1880 to 1930 and 1965 to 1998. In: MiN, Pyong Gap (orgs.) Mass Migration to the United States. Classical and Contemporary Periods. Walnut Creek, Altamira Press, 2002, pp.253-284. O maior fluxo de judeus, 49.947 pessoas, imigrou para o Brasil entre 1926 e 1942, tendo a maior parte se concentrado na cidade de São Paulo. LESSER, Jeffrey. $O$ Brasil e a questão judaica: imigração, diplomacia e preconceito. Rio de Janeiro, Imago, 1995. Os dados do Censo Nacional de 1991 indicam um total de 86.417 judeus no Brasil, dos quais 38.843 estabelecidos no município de São Paulo. DECOL, René Daniel. Judeus no Brasil: explorando os dados censitários. Revista Brasileira de Ciências Sociais, São Paulo, $n^{\circ}$ 46, 2000, 1 CD (Coleção da Revista Brasileira de Ciências Sociais, ANPOCS, 25 anos). Em 1993, a população judaica nos Estados Unidos era estimada em 5.8 milhões de pessoas, e a população da área metropolitana de Nova York em 1.450 .000 pessoas. KOSMIN, B. A.; SCHECKNER, J. Jewish population in the United States, 1993. In: SingER, D.; SELDIN, R. R. (orgs.) American jewish year book 1994. New York, The American Jewish Committee, 1994, pp.206-226.

${ }^{4}$ Nessa primeira fase da pesquisa ainda víamos a mulher como protagonista, da mesma forma que os poucos estudos sobre mulheres imigrantes realizados no país, entre os quais, destacamos os da autoria de SAKURAI, C. Romanceiro da imigração japonesa. São Paulo, Sumaré/FAPESP, 1993 e de LERNER, K. Fragmentos do passado: histórias de vida de mulheres imigrantes judias. Dissertação de Mestrado em Comunicação e Cultura, Escola de Comunicação, Universidade Federal do Rio de Janeiro, 1996. De forma semelhante, as obras 
Ethel V. Kosminsky

da categoria gênero, devemos evitar a falácia comum de tratar gênero como se dissesse respeito unicamente às mulheres.

publicadas nos Estados Unidos na década de 1980 também procuravam evidenciar a presença da mulher no processo migratório, criticando os estudos anteriores que focalizavam como sujeito somente o masculino. Entre esses autores, gostaria de destacar EWEN, E. Immigrant Women in the Land of Dollars: Life and Culture on the Lower East Side, 1890-1925. New York, Monthly Review Press, 1985 e WeInBERG, Sydney S. The World of our Mothers. The Lives of Jewish Immigrant Women. Chapel Hill, The University of North Carolina Press, 1988. Em ambos os países as obras foram escritas por mulheres. Em 2002 tivemos acesso à obra de Barrie Thorne, passamos então a entender gênero como uma categoria teóricometodológica fundamental para os estudos migratórios. THORNE, B. Feminism and the... Op. cit. Na década de 1990 os temas de família e gênero foram incorporados aos estudos migratórios produzidos nos Estados Unidos. Steven Gold elenca três motivos para essa mudança. Em primeiro lugar, o aumento do número de mulheres imigrantes. Assim, um dos aspectos que define a "nova imigração" é o seu grande contingente feminino. Em segundo lugar, a crescente influência do feminismo acadêmico, que coloca a experiência da mulher no centro da produção do conhecimento. Finalmente, a presença de um grande número de mulheres imigrantes tem acarretado implicações políticas relevantes, no sentido de reivindicações por melhores moradias e por mais extensivos serviços de assistência social, tornando-as o centro da pesquisa.

No Brasil, a influência do feminismo na academia, apesar dos trabalhos pioneiros de Helleieth Safiotti e de Eva Blay, aparece mais tarde com a criação de núcleos de pesquisas e de estudos de gênero, na década de 1980. GolD, S. Gender and Social Capital among Israeli Immigrants in Los Angeles. Diáspora, Havana, vol. 4, $\mathrm{n}^{\circ}$ 3, 1995, pp.267-301; SAFFIOTI, H. A mulher na sociedade de classes. mito e realidade. São Paulo, Quatro Artes, 1969; BlAY, E. As prefeitas. Rio de Janeiro, Avenir, 1981; SCAvONE, L. Feminismo e Ciências Sociais. Tese de LivreDocência, Faculdade de Ciências e Letras, Universidade Estadual Paulista, Araraquara, 2001. (A ser publicada em 2004, pela EDUNESP, sob o título de: Dar a vida e cuidar da vida: feminismo e ciências sociais.) A produção bibliográfica sobre gênero como categoria analítica nos estudos migratórios nos Estados Unidos data da década de 1990 e no Brasil, da década de 2000. Recentemente, no Brasil, foram publicados dois artigos que trabalham com a perspectiva de gênero entre emigrantes brasileiros nos Estados Unidos, AssIs, G. O. "De Criciúma para o mundo" - os novos fluxos da população brasileira: gênero e rearranjos familiares. In: MARTES, A. C. B.; FlEISCHER, S. (orgs.) Fronteiras cruzadas. etnicidade, gênero e redes sociais. São Paulo, Paz e Terra, 2003, pp.199-230; e DEBIAGGI, S. D. Famílias brasileiras em um novo contexto 
Gênero em estudos comparativos de imigração

Gênero é uma categoria relacional. Assim, embora estejamos focalizando aqui as mulheres, tomamos sempre como referência a sua relação com os homens, ainda que estes nem sempre apareçam de forma explícita. ${ }^{5}$

A inclusão de gênero como categoria mediadora nos estudos migratórios proporciona ao pesquisador informações sobre as causas, conseqüências e processos da migração internacional, permitindo também uma ampliação da relação entre o local e o global. Quando o gênero é trazido à frente dos estudos migratórios, vários temas podem surgir, entre os quais, como mulheres $e$ homens vivenciam a imigração de forma diferenciada e como este fato interfere no seu assentamento. ${ }^{6}$

As entrevistadas, cujos relatos foram coletados na cidade de São Paulo entre o final de 1997 e o início de 1998, e na cidade de Nova York no ano de 1998, serão aqui designadas como segunda geração e os seus relatos compreendem as histórias de vida dos seus pais e o processo de adaptação das suas famílias. Os pais imigrantes serão aqui referidos como primeira geração. Os relatos das entrevistadas sobre seus pais serão aqui considerados não

cultural. In: MARTES, A. C. B.; FleISCHER, S. (orgs.) Fronteiras cruzadas... Op. cit., pp.175-197. No primeiro, a autora busca "a contribuição que a perspectiva de gênero pode trazer à análise das redes sociais na migração". (p.206). E no segundo, "o foco da pesquisa é a relação entre o processo de aculturação (mudanças culturais) $e$ as relações de gênero entre marido e esposa no novo país" (p.176). É interessante também apontar a presença de autores do sexo masculino entre os pesquisadores da área de gênero e migrações nos Estados Unidos.

${ }^{5}$ Estamos trabalhando atualmente na análise das entrevistas com os filhos de imigrantes, coletadas em 2001 e 2003, nas cidades de Nova York e de São Paulo, respectivamente. Posteriormente poderemos então comparar as estratégias de adaptação de homens e mulheres imigrantes.

${ }^{6}$ Pessar, P. The Role of Gender, Households, and Social Networks in the Migration Process: A Review and Appraisal. In: HiRSCHMAN, C.; KASINITZ, P.; DEWIND, J. (orgs.) The Handbook of International Migration: the american experience. New York, Russel Sage Foundation, 1999, pp.53-70. 
Ethel V. Kosminsky

somente dentro da perspectiva de gênero como também da posição social que as entrevistadas ocupam na sociedade.

A partir da escolha da primeira entrevistada, a coleta dos demais relatos foi realizada fazendo-se uso da técnica da bola de neve. Os critérios que definiram a escolha das mulheres foram a ascendência e o local de moradia. Assim, foram pesquisadas algumas filhas de imigrantes judeus procedentes da Europa Oriental que, na época do trabalho, residiam nas cidades de Nova York e de São Paulo. Coletei nove relatos de vida de mulheres que se encontravam na faixa dos 58 aos 78 anos de idade, na cidade de Nova York e de oito mulheres na faixa dos 38 aos 68 anos de idade, na cidade de São Paulo.

Na cidade de Nova York, a seleção da primeira entrevistada ocorreu no YIVO, Institute for Jewish Research, onde havia realizado uma prolongada estadia de pesquisa no ano de $1995 .{ }^{7} \mathrm{O}$ YIVO é um instituto de pesquisa, fundado por judeus da Europa Oriental, com o objetivo de recuperar e promover a cultura e a língua iídiche. ${ }^{8}$ Durante muitos anos ele teve uma posição marcadamente socialista no cenário da comunidade judaica norteamericana. Pelo fato de termos utilizado a técnica da bola de neve, as entrevistadas guardam uma certa semelhança entre si, embora nem todas mantenham contato com o YIVO. ${ }^{9}$ Os pais e as

7 Bolsa CAPES-Fulbright para a realização da pesquisa Judaísmo e Imigração: A História de uma Família.

8 Iídiche, língua falada pelos judeus Ahskenazim, basicamente o alemão da Idade Média com algumas palavras eslavas e em hebraico. Os caracteres são em hebraico.

9 Como os contatos para a obtenção das entrevistas partiram de um instituto de cunho socialista, esse fato distinguiu o grupo de mulheres dos homens entrevistados, grande parte dos quais habitantes do The Williams Residence, um antigo prédio na cidade de Nova York, destinado às pessoas com mais de 55 anos de idade, administrado pelo Exército da Salvação, cujos moradores precisam ter uma determinada renda para poderem nele residir. Suponho que uma grande parte dos seus moradores tenha sido trabalhadores de escritório, de empresas e do serviço público, e também profissionais liberais. A quase totalidade dos relatos desses entrevistados e daqueles indicados por conhecidos 
Gênero em estudos comparativos de imigração

mães das entrevistadas podem ser vistos como "intelectuaistrabalhadores", no dizer de uma das filhas. ${ }^{10}$ Além da preocupação que expressaram em "refazer o mundo", tiveram um anseio em preservar a língua, a literatura e a cultura iídiche.

$\mathrm{Na}$ cidade de São Paulo, tivemos uma maior participação na escolha das entrevistadas, pelo fato de termos uma rede de amigos na cidade, além de compartilhamos da mesma língua e da mesma cultura. Assim, partimos de vários contatos para darmos início à técnica da bola de neve. Esses contatos localizaram-se, entretanto, no mesmo grupo social, as camadas médias.

As mulheres entrevistadas, de ambas as cidades, pertencem às camadas médias, contando algumas com mais recursos financeiros do que outras. A maior parte tem formação universitária, algumas inclusive concluíram o mestrado $e$ o doutorado. Em termos profissionais, todas exerceram atividades remuneradas, com exceção de uma, e muitas ainda trabalham, exercendo atividades remuneradas na área de educação ou como voluntárias em organizações culturais e sociais judaicas, apesar de aposentadas. ${ }^{11}$

compreendeu a própria vida com pouquíssimas referências à participação política e a dos pais imigrantes. Um outro ponto ainda a destacar está na idade dos entrevistados norte-americanos, todos muito idosos, entre 80 e 90 anos de idade, de modo que alguns relatos foram sucintos e algumas informações confusas. Os relatos dos homens brasileiros, filhos de imigrantes, selecionados por indicação de conhecidos e amigos também contêm poucas referências políticas deles próprios e menos ainda dos seus pais. $\mathrm{O}$ mesmo aconteceu com as mulheres brasileiras com uma notável exceção, referente à atuação de um pai imigrante. Desse modo, a técnica da bola de neve possibilitou que atingíssemos diferentes grupos de pessoas em ambas as cidades, permitindo a apreensão de diversas histórias de vida que têm convergências e divergências entre si.

10 "Intelectuais-trabalhadores", no sentido de que eram trabalhadores intelectuais e militantes políticos de partidos de esquerda.

${ }^{11}$ Os nomes das entrevistadas norte-americanas, na sua maioria, são verdadeiros, com exceção de Roberta e Jane que são fictícios; Bea e Jo são apelidos; os nomes das brasileiras são todos fictícios. A lista das entrevistadas nos Estados Unidos por idade e profissão é a seguinte: Roberta, 71 anos de idade, diretora de Recursos Humanos do Departamento do Trabalho do Estado de 
Ethel V. Kosminsky

Por ser esta uma pesquisa qualitativa, a questão da representatividade se coloca: até que ponto os relatos das entrevistadas representam os mais de dois milhões de judeus, homens e mulheres, que se dirigiram para Nova York e os milhares que migraram para São Paulo? Fazendo um paralelo ao que dizem Baily e Ramella ${ }^{12}$, referindo-se à migração de uma família italiana para a Argentina, os judeus aqui referidos podem não representar todos os judeus que migraram para Nova York e para São Paulo, mas as suas experiências de vida, os seus valores $e$ as suas opiniões representam grande parte do processo geral de adaptação desse grupo étnico na época tratada e nas sociedades em que se fixaram.

Os padrões de atitudes e comportamentos relacionados ao gênero $e$ abrangendo trabalho $e$ família serão aqui vistos no sentido da sua apreensão e re-elaboração pelas filhas, isto é, quais padrões foram observados pelas filhas e como estas os expressaram durante as entrevistas. Esses padrões culturais, trazidos pelos imigrantes, em contato com as sociedades receptoras, foram provavelmente reformulados, tendo sido

Nova York, aposentada; Jane, 58 anos de idade, Diretora de Desenvolvimento do YIVO; Bea, 75 anos de idade, auxiliar de administração de um hospital, aposentada; Jo, 72 anos de idade, aposentada de escola pública, leciona alguns cursos de pós-graduação na City University; Gladys, 70 anos de idade, assistente social aposentada; Shirley, 70 anos de idade, professora de crianças do Estado, aposentada; Ellie, 67 anos de idade, professora de crianças aposentada, leciona em um Community College pertencente à City University of New York (CUNY); Martha, 78 anos de idade, bibliotecária aposentada; Marianna, 70 anos de idade, leciona música para crianças. As entrevistadas no Brasil: Célia, 68 anos de idade, secretária aposentada; Amélia, 68 anos de idade, trabalhou como secretária por um curto período de tempo até casar; Annie, 51 anos de idade, empresária; Clara, 38 anos de idade, psicóloga; Rosa, 72 anos de idade, lojista; Edna, 63 anos de idade, professora de ensino médio, aposentada; Helena, 67 anos de idade, professora de ensino médio, aposentada; Hana, 55 anos de idade, professora universitária aposentada.

${ }^{12}$ Baily, S.; Ramella, F. Introduction. In: One Family, Two Worlds. An Italian Family's Correspondence across the Atlantic, 1901-1922. New Brunswick, Rutgers University Press, 1988, pp.1-32. 
Gênero em estudos comparativos de imigração

também re-elaborados nesse processo de transmissão cultural geracional entre pais imigrantes e seus filhos. Os relatos das filhas sobre esses padrões não poderão ser vistos como simplesmente herdados ou verticalmente transmitidos. As tradições étnicoculturais consistem da seleção dos seus componentes, revisão de tradições culturais herdadas e invenção de novas tradições. ${ }^{13}$

\section{Trabalho e relações de gênero na Europa Oriental}

A questão do trabalho está intimamente relacionada à posição da mulher dentro da família. Assim, a mulher judia, tanto a casada quanto a solteira, na Europa Oriental, podia trabalhar no mercado em praça pública, ou numa pequena loja, vendendo pequenas mercadorias, tais como agulhas, linha etc. - como conta Helena, uma das entrevistadas em São Paulo, referindo-se à sua mãe, ainda solteira, na Polônia.

No entanto, raramente uma mulher casada trabalhava em fábrica ou em algum outro emprego assalariado que a mantivesse por longas horas fora de casa. Em primeiro lugar, a produção industrial na Polônia e na Rússia ainda estava em seu início e, em segundo lugar, o homem judeu via como ameaçador para o seu domínio e para o sacramento do matrimônio que uma mulher casada permanecesse em companhia de homens estranhos, muito embora o fato da mulher trabalhar fora, em si, não fosse problema. Pelo contrário, era considerada uma honra para a mulher casada com um religioso, que este se dedicasse aos estudos dos livros sagrados enquanto ela sustentava a família, encarregando-se do seu próprio negócio, do cuidado da casa e dos filhos. ${ }^{14}$

\footnotetext{
${ }^{13}$ MIN, P. G. Contemporary immigrants'advantages for intergenerational cultural transmission. In: MIN, P. G. (org.) Mass migration to the United States. classical and contemporary periods. Walnut Creek, Altamira Press, 2002, pp.135-160.

${ }^{14}$ GLENN, S. Daughters of the Shtetl: life and labor in the immigrant generation. 2a. ed., Ithaca, Cornell University Press, 1993.
} 
Esse relacionamento proporcionava à mulher autoridade familiar e um contato com o mercado e, de uma certa forma, com o mundo. Essa flexibilidade de gênero ao longo da divisão da responsabilidade de manutenção da família ajudou a modificar o domínio patriarcal e obscureceu as linhas entre os papéis de gênero. Não foi por acaso que muitas mulheres jovens romperam com a vida confinada que levavam, ainda na Rússia. ${ }^{15}$

A situação da filha judia, solteira, na Europa Oriental, era diferente. Premidas por necessidades financeiras, as moças judias dedicavam-se a aprender o ofício de costureira, buscando trabalho assalariado nas recém-abertas fábricas de confecção e também de cigarros na Rússia e na Polônia. Outras trabalhavam em alguma forma de produção caseira ou, em último caso, como empregadas domésticas. Como solteiras, as moças judias não estavam submetidas às mesmas estritas regras que ordenavam as ações $e o$ ir e vir das mulheres casadas. Pelo fato de serem solteiras, elas não ameaçavam o sacramento do matrimônio e nem o domínio do marido. ${ }^{16}$

\section{O Brasil que as imigrantes judias encontraram}

A partir do acúmulo de estudos de caso que documentam como homens e mulheres vivenciam a imigração de forma diferenciada e como o patriarcalismo é reconfigurado ou não como uma conseqüência da imigração, observamos a necessidade de discutir a relação entre imigração e patriarcalismo, sem perder de vista o impacto na vida dos imigrantes do gênero, da etnia, nacionalidade e classe social. ${ }^{17}$

Embora estejamos nos referindo à família patriarcal, precisamos deixar claro que não há um consenso a respeito da

${ }^{15}$ GlenN, S. Daughters of the Shtetl... Op. cit.; KeSSLER-HARRIS, A. A. Introduction. In: YeZIERSKA, A. Bread Givers. New York, Persea Books, 1975, pp.5-18.

${ }^{16}$ GLENN, S. Daughters of the Shtetl... Op. cit.

${ }^{17}$ PESSAR, P. The role of gender... Op. cit. 
Gênero em estudos comparativos de imigração

predominância da família patriarcal no Brasil. Vários autores têm criticado os trabalhos de Gilberto Freyre e de Antonio Cândido, entre os quais destacam-se Corrêa e Samara e Costa. ${ }^{18}$ Roger Bastide restringe a obra de Gilberto Freyre a uma determinada área do país, a da "zona dos engenhos" e a um determinado período, "até o fim do Império". Aponta a influência sobre a estrutura da família provocada pela vinda de imigrantes de diversas origens e pelo processo de industrialização. ${ }^{19}$

A análise elaborada por Kuznesof ${ }^{20}$ focalizando principalmente São Paulo, embora conte com dados de outras regiões, referente ao período compreendido entre os anos 1700 e 1980, mostra que muito embora a família patriarcal do passado colonial agrário-exportador possa ter desaparecido, subsiste uma ideologia em termos de poder do pai sobre a mulher $e$, especialmente, sobre as filhas, que atravessa todas as classes sociais. Como componente dessa ideologia persiste a oposição entre o lar e a rua; o lar visto como sagrado, inviolável, privado, o espaço por excelência das relações pessoais, do respeito e da lealdade, e a rua como o universo das relações impessoais, do comércio, da trapaça, da política e da lei. ${ }^{21}$ Apesar do século XX ter visto uma maior independência da mulher, dos filhos e filhas em todas as classes, os mecanismos de suporte da família, ou seja,

${ }^{18}$ FREYRE, G. Casa grande e senzala: formação da família patriarcal brasileira sob o regime de economia patriarcal. 25 ed., Rio de Janeiro, J. Olympio, 1987 [1933]; CÂNDIDO, A. The brazilian family. In: SMITH, T. L.; MARCHANT, A. (orgs.) Brazil: portrait of half a continent. New York, Dryden, 1951, pp.291-312; CORRÊA, M. Repensando a família patriarcal brasileira. In: ARANTES, A. et alii. (orgs.) Colcha de retalhos. São Paulo, Brasiliense, 1982, pp.13-38; SAMARA, E. M.; CostA, D.I.P. Family, Patriarchalism, and Social Change in Brazil. Latin American Research, Albuquerque, vol. 32, nº 1, 1997, pp.212-225.

${ }^{19}$ BASTIDE, R. A monografia familiar no Brasil. Revista do Arquivo Municipal, São Paulo, ano 7, vol. 78, ago-set. 1941, pp.5-26.

${ }^{20}$ KuzNESOF, E. A. A família na sociedade brasileira: parentesco, clientelismo e estrutura social (São Paulo, 1700-1980). Revista Brasileira de História, São Paulo, vol. 9, n. 17, set.1988/fev.1989, pp.37-63.

${ }^{21}$ DA MATTA, R. A casa e a rua. São Paulo, Brasiliense, 1985. 
as redes de relações pessoais, a importância da parentela, as categorias atribuídas persistem em todos os aspectos da sociedade brasileira.

Dentro dessa discussão sobre imigração e patriarcalismo, Antonio Cândido afirma que a imigração pode contribuir para a manutenção dos antigos padrões, "não somente porque os imigrantes adotam traços semi-patriarcais através do contato cultural, mas porque em muitos casos eles próprios são portadores de traços semelhantes. ${ }^{22}$ Este é, por exemplo, o caso dos italianos do sul da península, com as suas tendências fortemente paternalísticas, e, acima de tudo, com os sírios, ainda imersos em uma organização semi-patriarcal que eles defendem tenazmente através da segregação e do casamento consangüíneo". ${ }^{23} \mathrm{~A}$ observação a respeito da organização familiar dos sírios foi corroborada por uma pesquisa recente sobre sírios e libaneses em São Paulo, que mostra a persistência do padrão patriarcal na colônia. ${ }^{24}$

No Brasil, o trabalho da mulher casada, fora de casa, não era bem visto. $\mathrm{Na}$ cidade de São Paulo, mulheres e moças, adolescentes e crianças das classes trabalhadoras, na sua maioria de origem italiana, eram empregados em indústrias de fiação $e$

\footnotetext{
${ }^{22}$ Alguns trabalhos mostram a diversidade de tipos de família, de acordo com o local, a classe social e a etnia do grupo estudado. Constatamos, por exemplo, o crescimento significativo da família matrifocal nas camadas mais pobres da população. KOSMINSKY, E. A situação familiar das crianças e adolescentes pobres: um estudo dos indicadores sociais no Brasil. Cadernos CERU, São Paulo, $\mathrm{n}^{\circ} 5$, série 2, 1994, p.92. No entanto, parte das observações de Antonio Cândido se coaduna com a nossa pesquisa sobre a família Feldman, cujos pais eram imigrantes judeus da Europa Oriental que se fixaram no Nordeste brasileiro por volta de 1910, quando então observamos a preocupação do chefe da família em fornecer educação superior aos seus filhos, enquanto que as mulheres eram destinadas ao casamento. KOSMINSKY, E. Judaísmo e imigração: a história de uma família. Relatório científico apresentado à FUNDUNESP, São Paulo, 1996.

${ }^{23}$ CÂNDIDO, A. The brazilian family. Op. cit., pp.306-307.

${ }^{24}$ TRuzzi, O. De mascates a doutores. sírios e libaneses em São Paulo. São Paulo, Sumaré, 1992, p.93.
} 
Gênero em estudos comparativos de imigração

tecelagens. No final de 1920, a crítica ao trabalho feminino nas fábricas, exercida por autoridades sanitárias e policiais, educadores, políticos, imprensa e operariado, aparece justificada pelo aumento da delinqüência infanto-juvenil, incidência da mortalidade infantil, restrição de oportunidades de trabalho para o operário adulto do sexo masculino, e pelas conseqüências nocivas para a moral e a organização da família. Essas críticas, apoiandose nas péssimas condições de trabalho, na insuficiência da legislação e na ausência de equipamentos de uso coletivo, continham um componente tradicionalista, segundo o qual a mulher destinava-se à vida doméstica e à procriação. ${ }^{25}$

A maior parte das mulheres das classes trabalhadoras, todavia, ocupava-se em serviços que eram uma extensão das atividades domésticas, tais como costurar, lavar, cozinhar. Dessa forma, o emprego doméstico constituía a principal fonte de trabalho para a mulher. Outras trabalhavam como vendedoras, nas ruas das cidades. ${ }^{26}$

As mulheres e moças da elite, na cidade do Rio de Janeiro, que no final do século XIX, precisavam de um homem da família que as acompanhasse quando iam fazer compras, no início do século XX, já começavam a sair à tarde, mães e filhas, para passearem na avenida principal e para freqüentarem as casas de chá. No entanto, a vida social continuava centrada na família e na ampla rede de parentesco. As mulheres da elite viviam confinadas principalmente ao círculo familiar. $\mathrm{O}$ marido ainda permanecia legalmente o chefe da família e a mulher era considerada legalmente incapaz. ${ }^{27}$

Nos primeiros anos do século XX, alguns sinais de mudança na vida das mulheres, pertencentes à elite e às camadas médias,

${ }^{25}$ MouRA, E.B.B. Mulheres e menores no trabalho industrial: os fatores sexo e idade na dinâmica do capital. Petrópolis, Vozes, 1982.

${ }^{26}$ HAHNER, J.E. Emancipating the female sex: the struggle for women's right in Brazil, 1850-1940. 2rd. ed., Durham, Duke University Press, 1993.

${ }^{27}$ ID., IB. 
começaram a aparecer, entre esses o aumento da entrada de moças nas escolas normais. Esse fato ajudou a ampliar o horizonte das moças e a fomentar o vagaroso índice de alfabetização do país. No entanto, pouquíssimas moças, formadas pelas escolas normais, conseguiram entrar nas profissões da elite - direito e medicina. Aquelas que assim o fizeram e se tornaram profissionais, enfrentaram discriminação, apesar de pertencerem à elite. ${ }^{28}$

Naquela época, no centro-sul do país, um pequeno número de mulheres começou a trabalhar para o governo, nos escritórios dos correios e telégrafos e da estrada de ferro. Com o crescimento do sistema bancário, de agências de seguro e de estabelecimentos comerciais, moças e mulheres das camadas médias passaram a encontrar trabalho e a ocupar as chamadas posições de colarinho branco. Tanto nas fábricas quanto nos escritórios, as mulheres ganhavam menos do que os homens, e o seu trabalho era visto como uma ocupação temporária anterior ao casamento ou como uma complementação provisória do salário do marido ou dos pais. ${ }^{29}$

No início da década de 1920, as atividades de grupos feministas crescem no Brasil, incluindo o movimento sufragista, restrito às classes alta $e$ média urbanas. Os problemas concernentes às mulheres das classes trabalhadoras permaneciam. A clivagem da sociedade de então não era somente de classe social, era também de etnia. Assim, as mulheres negras ocupavam a posição mais baixa da escala social, seguidas das mulheres brancas imigrantes e pobres.

São Paulo encontrava-se em processo de industrialização e os judeus ocuparam o lugar de intermediário, como vendedor ambulante (klienteltchik), ou dono de oficinas de confecções e de bazares, baseando-se na sua experiência na Europa Oriental. ${ }^{30}$

\footnotetext{
${ }^{28}$ ID., IB.

${ }^{29}$ ID., IB.

${ }^{30}$ RATTNER, H. Economic and social mobility of jews in Brazil. In: ElkIN, J.; MERKX, G. (orgs.) The jewish presence in Latin America. Boston, Allen \& Unwin, 1987, pp.187-200.
} 
Gênero em estudos comparativos de imigração

Habitando na sua maioria o bairro do Bom Retiro, os imigrantes judeus compartilharam da mesma pobreza que os demais imigrantes, vivendo em cortiços e quartos alugados em casas de família. As mulheres judias encontraram uma situação ambígua, precisavam trabalhar, mas o trabalho da mulher não era bem visto, nem pelos seus próprios conterrâneos e nem pelos brasileiros. ${ }^{31}$ No entanto, era socialmente respeitado trabalhar junto com o marido em oficinas de confecção ou em bazares e, em casa, fazendo acabamento de roupas, no caso do marido ser alfaiate. Uma grande parte das mulheres permaneceu como dona de casa, algumas completavam a renda recebendo pensionistas. ${ }^{32}$

A ascensão social dos imigrantes judeus que se dirigiram para São Paulo, nas décadas entre 1920 e 1940, foi rápida. Tendo ingressado nos setores mais dinâmicos da sociedade brasileira, em alguns anos, passaram de vendedores ambulantes e de artesãos a lojistas e proprietários de fábricas. ${ }^{33}$

${ }^{31}$ Kosminsky, E Os judeus no bairro do Bom Retiro (São Paulo: 1925-1955). Cadernos CERU, São Paulo, série 2, n 13, 2002, pp. 47-71.

${ }^{32}$ Das oito mulheres imigrantes, quatro trabalhavam e quatro não trabalhavam. As quatro que trabalhavam, se ocupavam da seguinte forma: uma cuidava da loja juntamente com o marido; uma era representante comercial da oficina de confecções que tinha com o esposo; uma trabalhou no mercado de capitais junto com o marido e, mais tarde, abriu temporariamente uma loja de presentes com uma amiga; e finalmente, uma fazia serviços eventuais de costura, em casa, ajudando o marido que trabalhava como fornecedor de ternos. O trabalho das quatro mulheres estava pois relacionado às atividades dos maridos. Entre as quatro que não trabalhavam fora, uma recebia pensionistas em casa. Das oito mulheres, quando jovens, apenas uma trabalhou, assim que chegou, numa fábrica de bolsas. Essa é aquela que, mais tarde, tornou-se representante de vendas.

${ }^{33}$ Quanto à ocupação dos homens imigrantes, tem-se que, dos oito homens imigrantes, sete começaram a trabalhar como mascates e apenas um como "guia turístico", ou em qualquer outro "negócio", segundo sua filha. Neste último caso, trata-se de um imigrante pós-guerra (1948). Dos sete que trabalharam como mascates, seis vendiam cortes de tecidos e um era mascate-artesão, isto é, ele batia de porta em porta, recolhendo relógios para consertar. O passo seguinte dos entrevistados apresentou uma diversidade maior, dos oito homens imigrantes, três abriram lojas (tecidos, confecções, armarinho, respectivamente); 
Ethel V. Kosminsky

\section{Os Estados Unidos que as imigrantes judias encontraram}

Nos Estados Unidos, embora a organização familiar também fosse baseada na autoridade paterna, isto é, baseada na supremacia do homem sobre a mulher $e$ os filhos, a estrutura social, na época da chegada dos imigrantes, era baseada de forma evidente nos relacionamentos de classe e não como no caso da sociedade brasileira, em que as relações de classe eram imbuídas de relações pessoais, nas quais os laços de parentesco se sobressaíam. Os imigrantes encontraram uma sociedade industrializada que oferecia oportunidades de trabalho para homens e mulheres. No entanto, a cultura norte-americana censurava o trabalho da mulher casada fora de casa. As famílias da classe trabalhadora $e$ imigrante não compactuavam completamente com essa norma. No caso dos imigrantes francocanadenses, as mães trabalhavam até os filhos e filhas entrarem na força de trabalho, quando então as mães iam gradualmente se retirando. ${ }^{34}$

As imigrantes judias, casadas, raramente trabalhavam em fábricas ou oficinas. De acordo com os costumes ortodoxos, as esposas judias não podiam ter contatos com outros homens, a não ser o marido. Não podiam ser submetidas à autoridade de um

um abriu uma oficina de consertos de relógio, um deu início a uma alfaiataria, um começou uma firma de exportação e importação, um foi trabalhar em um açougue, tendo-se tornado sócio, e um permaneceu mascate. Os imigrantes prosseguiram na luta pela melhoria das suas condições de vida e, assim, tem-se que dos oito homens, cinco passaram a ter lojas, um passou a trabalhar com o mercado de capitais; um se tornou fornecedor de ternos prontos e de aviamentos e peles; um permaneceu trabalhando como mascate. Das cinco lojas, três eram de tecidos e confecção, uma de móveis e outra, além do conserto de relógios, o seu proprietário vendia jóias populares. Observa-se que houve um crescimento do número de proprietários de lojas e oficinas em comparação com o momento anterior.

${ }^{34}$ HAREVEN, T. Family time \& industrial time: the relationship between the family and work in a New England Industrial Community. Lanham, University Press of America, 1993. 
Gênero em estudos comparativos de imigração

empregador do sexo masculino ou manterem contato com homens estranhos. Essa possibilidade assustava muito mais o marido do que o próprio trabalho da mulher. Prevalecendo as normas anteriores à imigração, era permitido para as mulheres casadas somente o trabalho por conta própria no negócio da família, em uma pequena loja, ou como vendedora ambulante com um carrinho de mercadorias (peddler), ou o trabalho realizado em casa, para a indústria de confecção, trabalhos por peça ou acabamento de roupas e a confecção de flores artificiais. Receber pensionistas em casa, os imigrantes recém-chegados, prática já exercida na Rússia e na Polônia, constituiu-se na principal atividade econômica exercida pelas esposas judias nos Estados Unidos. As filhas (solteiras) substituem a mãe no trabalho externo, assalariado, realizado em oficinas e fábricas de confecções e de chapéus. Na maior parte das famílias, o trabalho das filhas possibilitou às mães permanecerem em casa. ${ }^{35}$

A sexualidade das filhas, no entanto, não era socialmente reconhecida como no caso de suas mães, isto é, não se esperava que elas mantivessem uma vida sexual sendo solteiras. Não sendo casadas, elas não comprometiam a santidade do casamento ou não ameaçavam o domínio do marido pelo fato de trabalharem em fábricas ou oficinas, onde elas tinham contato com empregadores e empregados do sexo masculino. ${ }^{36}$

Com a imigração, as mulheres passaram a viver em uma sociedade secularizada, a participar ativamente de movimentos reivindicativos (contra o aumento dos preços dos alimentos e dos aluguéis), de sindicatos e de grupos políticos, o que afetou a sua inserção na sociedade $e$ as relações de gênero na família $e$ no trabalho.

Dentro da classe trabalhadora, as relações patriarcais dividiam as vidas $e$ as consciências dos homens e das mulheres. A cultura pública dos homens trabalhadores era não somente uma

${ }^{35}$ GLENN, S. Daughters of the Shtetl... Op. cit.

${ }^{36}$ ID., IB. 
Ethel V. Kosminsky

barreira potencial de solidariedade contra o capitalismo, como também um sistema de privilégio masculino, no qual a autodeterminação, a solidariedade $e$ a ajuda mútua eram entendidas como masculinas. O tempo das mulheres diferia do dos homens, modelado pela divisão sexual que estruturava o trabalho, o acesso a recursos e a participação na vida pública. O lazer das mulheres, pelo menos o das mulheres casadas, tendia a ser segregado da esfera pública e não se diferenciava de forma notável do trabalho, pois era entrecruzado com os ritmos do trabalho de casa e das relações de parentesco. ${ }^{37}$

De acordo com as culturas imigrantes que dominavam a classe trabalhadora urbana daquela época, as mulheres jovens tinham que cumprir o seu papel de filhas, ajudar com o serviço da casa depois do trabalho, entregar o envelope do seu pagamento fechado e seguir as tradições do Velho Mundo sobre a participação social das mulheres que em alguns casos era muito restritiva. Ao mesmo tempo, a vida das mulheres jovens e solteiras estava sujeita a mudanças rápidas. Como assalariadas elas vivenciavam ritmos de tempo e de trabalho mais semelhante aos dos homens do que aos das mulheres casadas. A cultura das oficinas e fábricas reforçava a noção de que o lazer era um tipo de atividade ao qual as mulheres trabalhadoras podiam ter acesso. Contudo, as mulheres jovens não se dirigiram para o domínio tradicional masculino, mas para as formas emergentes de lazer pago, tais como salóes de dança, parques de diversão e teatros.

À medida que o lazer deixava de ser de domínio masculino, as diversões pagas passaram a receber jovens de ambos os sexos, onde a participação da mulher era bem vinda e encorajada. Muitas mulheres jovens, especialmente as filhas de imigrantes, passaram a identificar as diversões a baixo preço com a integração na cultura norte-americana urbana, particularmente com o seu

\footnotetext{
${ }^{37}$ PEISS, K. Cheap amusements. working women and leisure in turn-of-the-
} Century New York. Philadelphia, Temple University, 1986. 
Gênero em estudos comparativos de imigração

individualismo, a ideologia do consumo e o namoro sem o controle dos pais. ${ }^{38}$

A complexa passagem da cultura vitoriana para o modernismo provocou, entre outras mudanças, uma redefinição das relações de gênero. No fim do século XIX, a cultura dominante com os seus valores de mundos espaciais e sociais segregados para homens e mulheres burgueses, com os seus preceitos de domesticidade, de guardiã da moralidade e de pureza sexual, havia transformado em dever moral e social as tradicionais tarefas domésticas e o cuidado com as crianças. As mulheres das classes médias imbuídas desses valores procuravam divulgar essas ideais, especialmente o da domesticidade, para as mulheres das classes trabalhadoras. ${ }^{39}$

Por volta daquela época, essa construção cultural dominante começou a ser reformulada, atingida pelas mudanças das vidas das mulheres. O movimento das mulheres em busca de emprego, de educação superior e o ativismo político ampliaram o lugar das mulheres. A força das demandas feministas por maiores direitos políticos e oportunidades econômicas desafiava a divisão de poder na sociedade norte-americana. Em contraste com a ideologia vitoriana da separação espacial e psicológica, uma preocupação cultural com os laços emocionais e sexuais entre homens e mulheres desenvolveu-se nas primeiras décadas do século XX. Contudo, o discurso público afirmando o companheirismo entre a mulher moderna e o homem obscurecia a nova reformulação cultural da subordinação das mulheres. As mulheres permaneciam atadas aos seus relacionamentos conjugais. $^{40}$

Em agosto de 1920, as mulheres norte-americanas conseguem o direito do voto. Todo esse panorama até agora traçado refere-se apenas às mulheres brancas, habitantes das

\footnotetext{
${ }^{38}$ ID., IB.

${ }^{39}$ ID., IB.

${ }^{40}$ ID., IB.
} 
Ethel V. Kosminsky

cidades, imigrantes e filhas de imigrantes. Certamente o movimento feminista nos Estados Unidos, do qual muitas mulheres judias participaram, deve ter tido a sua parcela de responsabilidade nessas alterações. O papel marcante que as mulheres judias desempenharam nos movimentos de libertação feminina nos anos 1950 e 1960 não foi obra do acaso. Por décadas, nesse país, as mulheres judias estavam entre as ativistas que conduziram as campanhas pelos direitos civis, pelo desarmamento nuclear e pela paz. ${ }^{41}$

A história de muitas mulheres imigrantes judias, solteiras, que imigraram para os Estados Unidos nas primeiras duas décadas do século $\mathrm{XX}$, pode ser assim resumida: trabalho assalariado, participação em sindicatos, casamento e maternidade, algumas vezes acompanhada pela "ajuda" nos negócios da família ou pelo retorno temporário à fábrica para contribuir com alguma renda extra.

A inserção dos imigrantes judeus na cidade de Nova York seguiu um processo diferente daquele de São Paulo. A sociedade norte-americana industrializada, moderna, necessitava de mão-deobra para suas fábricas e a grande maioria dos imigrantes judeus foi trabalhar na indústria de confecções.

Somente a partir da segunda geração, que emergiu em 1920, é que teve início o processo de ascensão social, expresso no fato de que, desta data em diante, algumas mulheres judias da segunda geração conseguiram se tornar professoras da escola pública. A seleção burocratizada e impessoal para o cargo de professora $^{42}$ possibilitou a muitas mulheres judias vencerem a barreira dos preconceitos encontrados nos empregos do tipo colarinho-branco. ${ }^{43}$

${ }^{41}$ ANTLER, J. The journey home: jewish women and the American Century. New York, The Free Press, 1997.

${ }^{42}$ Moore, D. D. At home in America: second generation New York Jews. New York, Columbia University Press, 1981.

${ }^{43} \mathrm{O}$ anti-semitismo nos Estados Unidos tornou-se visível da segunda metade do século XIX até o final da década de 1950 aproximadamente, tendo apresentado 
Gênero em estudos comparativos de imigração

\section{Mães e filhas na cidade de Nova York}

Os imigrantes judeus viviam em tenements no Lower East Side de Nova York, onde a densidade populacional era, naquela época, uma das maiores do mundo. Além das difíceis condições de moradia, enfrentavam o trabalho assalariado sazonal na indústria de confecção. Os imigrantes judeus nos Estados Unidos

um caráter discriminatório que se manifestava na perseguição aos mascates judeus nas ruas das cidades grandes (Nova York, Chicago e outras), nas dificuldades de alugar casa fora do bairro de maioria judaica, de conseguir emprego - os empregadores no setor de serviços anunciavam nos jornais pedindo que apenas cristãos se apresentassem - de arrumar hospedagem em hotéis, de serem aceitos nas principais universidades privadas do país. HIGHAM, John. Send These to Me: Immigrants in Urban America. 3rd. ed. rev., Baltimore, The Johns Hopkins University Press, 1993. Entre as nossas entrevistadas, podemos citar o caso do pai de Roberta, que quando viajava a trabalho precisava que o seu chefe reservasse um quarto de hotel em seu nome para que ele pudesse se hospedar. Entre os homens entrevistados, Gerson, filho de imigrantes, nos forneceu uma fotocópia do "New York Herald Tribune", datado de fevereiro de 1941, contendo anúncios de emprego, nos quais os empregadores solicitavam unicamente cristãos. Contou que, "para um jovem judeu era muito difícil arrumar emprego, a não ser que ele trabalhasse para outro judeu". No Brasil, o anti-semitismo, daquele período, não apresentou esse caráter discriminatório. Sem entrar na discussão sobre o anti-semitismo político $e$ ideológico, em ambos os países, e considerando apenas aquele que se manifestava de forma socialmente discriminatória, em São Paulo, entre as entrevistadas, uma relatou que, na década de 1950, o seu marido tentou ser juiz, foi um dos primeiros colocados no concurso e "não entrou por ser judeu". Ela e uma outra entrevistada relataram casos de anti-semitismo no clube Paulistano. Para a primeira, o anti-semitismo no Brasil é "velado". Cremos que essa colocação mostra bem a diferença entre ambos os países em relação à questão. Os homens entrevistados não se referiram à experiência de discriminação antisemita. Quanto à geração imigrante, em São Paulo, os judeus mascates eram conhecidos como "o russo da prestação", provavelmente em virtude de terem entrado no país portando um passaporte russo. Não encontramos referências entre os(as) entrevistados (as) a respeito de discriminação social enfrentada pelos pais (homens e mulheres) imigrantes. 
Ethel V. Kosminsky

enfrentaram uma sociedade competitiva marcada pela segregação racial $e$ pelo anti-semitismo. ${ }^{44}$

Na cidade de Nova York, as famílias judias apresentaram um alto índice de abandono do lar pelo marido. ${ }^{45}$ Esse dado pode ser um indicativo da tensão do processo de adaptação vivenciado pelas famílias imigrantes. Diante do abandono ou da morte do marido, a mulher, com filhos pequenos, teria, possivelmente, como única opção colocar as crianças em um orfanato e procurar trabalho. Conta Bea, uma das entrevistadas, que a sua tia, irmã do seu pai, que havia imigrado antes dele, com a morte do marido, por tuberculose, precisou internar as crianças "em um orfanato, por um tempo, até que ela pudesse começar a costurar para as pessoas e ganhar dinheiro e então ela as retirou do orfanato". Completa Bea: "As coisas eram difíceis, elas eram mesmo muito ruins".

O abandono da família pelo homem pode estar também relacionado às diferenças de expectativa dos papéis masculino $e$ feminino nos Estados Unidos. Para a cultura ocidental, o homem era (e ainda é, em muitos casos) visto como o provedor principal da família, diferente da posição ocupada na Europa Oriental, na época da emigração, quando então o casal tinha uma relação de parceria. ${ }^{46}$ Anzia Yezierska, em Bread Givers ${ }^{47}$, publicado pela primeira vez em 1925, mostra as dificuldades de adaptação de um

${ }^{44}$ Tenements eram semelhantes ao que hoje chamamos de cortiço: apartamentos contendo um ou dois cômodos, muitos dos quais sem janelas, uma privada, por andar, compartilhada pelos moradores, apinhados de gente, enfim um foco de disseminação de doenças, tais como tuberculose, agravando as condições de saúde física e mental dos seus moradores. Em apartamentos como esses moravam as famílias imigrantes e os seus pensionistas. Rischin, M. The promised city. New York's Jews, 1870-1914. Cambridge, Harvard University Press, 1977.

${ }^{45}$ MetzKer, I; Golden, H. A bintel brief. New York, Shoken Books, 1971. GlENN, S. Daughters of the Shtetl... Op. cit.

${ }^{46}$ Glenn, S. Daughters of the Shtetl... Op. cit.; Kessler-HarRIS, A. A. Introduction. Op. cit.

${ }^{47}$ YeZIERSKA, A. Breadg Givers. Op. cit. 
Gênero em estudos comparativos de imigração

chefe de família, ocupado com o estudo do Torah, no seu antigo shtetf $^{8}$ e a vida na "América, onde tudo é somente negócio e negócio". ${ }^{49}$ Para as mulheres casadas e com filhos pequenos, o processo migratório significou a perda do suporte da família mais ampla, além das diferenças culturais quanto ao serviço doméstico.

$\mathrm{Na}$ família imigrante judia, na cidade de Nova York, como já foi descrito, a maioria das mulheres casadas trabalhava em casa. Além disso, existiam as tarefas de casa: limpar, lavar a roupa, comprar comida, cozinhar e cuidar das crianças. A realização de cada uma dessas tarefas era esgotante, consumindo muito tempo. A compra de alimentos exigia longas caminhadas à procura de preços que permitissem economizar alguns pennies. As péssimas condições dos tenements, o seu exíguo espaço, a falta de local adequado para lavar a roupa e banhar as crianças, tudo isso dificultava bastante a vida das mães imigrantes. ${ }^{50}$

Comparando com a vida nas cidadezinhas da Europa Oriental, em que as casas eram simples abrigos $e$ onde as mulheres costumavam lavar a roupa no rio, em pequenos grupos, havia um grande contraste com a vida na cidade de Nova York. As diferenças de costumes, novas regras de comportamento $e$ diferentes padrões de limpeza eram exigências que se faziam sentir, e que eram incompatíveis com as duras condições de vida. Mesmo para as mulheres que procediam de cidades grandes, tais como Varsóvia, Vilna, Odessa, as dificuldades foram muitas. ${ }^{51}$

48 Shtetl, em iídiche, cidadezinha.

49 "America, where everything is only business and business".

${ }^{50}$ GLENN, S. Daughters of the Shtetl... Op. cit.; RISCHIN, M. The promised city... Op.cit.

${ }^{51}$ Poder-se-ia supor que o fato do imigrante judeu ter sido originário de uma cidade grande poderia de uma certa forma influenciar a sua inserção na sociedade norte-americana e, de modo específico no mercado de trabalho. Entretanto, parece que ocorreu uma tendência da sociedade receptora de nivelar, de homogeneizar as pessoas a partir da sua entrada no mercado de trabalho e das próprias forças internas à sociedade norte-americana, tais como, o processo de americanização, isto é, a imposição das normas e valores dominantes, e o anti-semitismo. KOSMINSKY, E A presença da Europa Oriental 
Anzia Yezierska, na sua obra de cunho auto-biográfico, publicada pela primeira vez em 1920 , refere-se ao preconceito e às dificuldades enfrentadas pela jovem imigrante que dividia o seu tempo entre o trabalho numa lavanderia $e$ as aulas de uma faculdade, que com muito esforço pagava, e a crítica à sua aparência da parte da diretora: "Sabonete e água são baratos. Qualquer um pode ficar limpo". ${ }^{52}$ Como ela poderia se manter tão limpa e com a roupa passada se trabalhava das $5 \mathrm{~h}$ às $8 \mathrm{~h}$, antes de ir para a faculdade, $e$ das $6 \mathrm{~h}$ às $23 \mathrm{~h}$, quando acabavam as aulas $e$ os estudos? E afinal nem banheira ela tinha na casa onde morava.

Shirley, uma das entrevistadas, conta as dificuldades enfrentadas pela sua mãe - órfã, imigrou com a idade de 13 anos, tendo se casado com a idade de dezenove anos - ocupada com as tarefas domésticas e os cuidados com os filhos:

Depois do casamento, minha mãe parou de trabalhar, ela ficava em casa cuidando dos filhos. Ela teve muitos problemas porque ela não tinha quem a ajudasse. Ela não tinha mãe. Ela me contava histórias, ela não sabia cozinhar, então ela perguntava para alguém como fazer. A primeira vez, ela lavou alface com água e sabão, ela não sabia coisa alguma. (...) Histórias do meu irmão mais velho que gostava muito de música, ele ouvia o som de um órgão $e$ pulava a cerca. A polícia o trazia de volta e brigava com a minha mãe até que, por fim, ela o amarrava a uma árvore.

As crianças, meninas e meninos, trabalhavam - a idade legal para o trabalho era dezesseis anos, o que nem sempre era observado -, sendo o seu ganho um importante componente da renda da família. Conta Bea, nascida na cidade de Nova York:

Judaica nas Américas (Nova York e São Paulo): Relatos de filhas sobre pais imigrantes. 2000. Tese de Livre-Docência, Departamento de Sociologia e Antropologia, Faculdade de Filosofia e Ciências, Universidade de São Paulo, Marília, 2000.

52 "Soap and water are cheap. Any one can be clean." YezIERSKA, A. Hungry Hearts \& other stories. New York, Persea Books, 1985. 
Gênero em estudos comparativos de imigração

Quando eu estava com seis anos de idade, (...) os meus pais tinham uma oficina de roupas prontas, também na Clinton Street, e eu ajudava o máximo possível. Eu costumava arrumar a vitrine, escolher as roupas (...) e eu mesma atendia os fregueses, quando os meus pais estavam ocupados com outras coisas ou com outros fregueses.

Com a idade de dez anos, a mãe de Ellie - imigrante que perdeu a mãe com a idade de cinco anos e cujo pai casouse novamente, sendo mal-tratada pela madrasta - foi trabalhar em uma fábrica, abandonando a escola no Lower East Side.

Entre as familias judias havia uma diferenciação conforme a posição ocupada pelos filhos e filhas por ordem de nascimento. Os filhos mais velhos, homens e mulheres, tão logo chegavam na cidade de Nova York, iam direto para o trabalho nas fábricas ou ajudavam os pais, quando estes trabalhavam por peça, em casa, ou quando as mães confeccionavam flores. Conta Bea, referindose ao seu irmão, imigrante, quase dez anos mais velho:

Ele tinha uma grande responsabilidade. Ele tinha que ajudar os meus pais, que não sabiam ler ou escrever em inglês. Quando ele chegou, ele não sabia falar inglês, mas ele aprendeu muito depressa na escola e ele então recebia os pedidos, tirava as medidas dos fregueses quando a minha mãe precisava fazer as roupas e ele também entregava as roupas. Naqueles dias, eles geralmente alugavam as roupas e quando eles não precisavam mais, ele as buscava. Ele tinha um bocado de trabalho para um garoto tão jovem. Cada criança em todas as famílias imigrantes, todas as crianças ajudavam o máximo que podiam.

As filhas mais velhas arcavam com a responsabilidade de participar com uma grande parte do sustento da família. Algumas chegavam mesmo a entregar todo o seu salário para as mães, que então lhes davam o suficiente para a sua manutenção diária. Se 
isso significava que elas conquistavam uma certa independência e melhoravam a sua posição dentro da família, ao mesmo tempo o trabalho que realizavam nas fábricas, as longas horas de permanência eram esgotantes e conduziam ao envelhecimento precoce e a uma série de doenças, como bem relata Rose Cohen $^{53}$, na sua autobiografia, cuja primeira edição data de 1918. $\mathrm{O}$ ambiente das fábricas e oficinas, em muitos casos, predominantemente masculino, era constrangedor. Ouviam-se piadas e palavrões e também, da parte dos patrões, tentativas de obtenção de favores sexuais. ${ }^{54} \mathrm{O}$ trabalho opressivo fazia com que as moças aspirassem $\mathrm{O}$ casamento, também como uma possibilidade de libertação do trabalho industrial.

Muitas moças imigraram com a aspiração de poderem freqüentar a escola e de ter acesso à educação, no entanto, essa possibilidade para a filha mais velha dificilmente se concretizou. Elas tinham que trabalhar para mandar buscar a família e para mantê-la quando da sua chegada. Assim, essa aspiração foi muitas vezes transferida para os irmãos e irmãs menores, tendo sido construída uma grande expectativa em relação aos irmãos, reproduzindo dessa forma os antigos padrões de comportamento que encontraram possibilidade de atualização na nova sociedade. Weinberg ${ }^{55}$ reproduz os relatos de vida de mulheres imigrantes em que se destaca a frustração do não poder freqüentar a escola.

Assim, além da idade, o sexo era fator importante na posição ocupada por filhos e filhas na família. Ellie recorda-se da história da sua mãe e da irmã e irmão desta, que, órfãos de mãe e de pai, foram morar em um

pequeno apartamento, um cômodo de trás do corredor que todos os inquilinos compartilhavam (...). Ela [a mãe] era

\footnotetext{
${ }^{53}$ COHEN, R. Out of the shadow. a Russian Jewish Girlhood on the Lower East Side. 2rd. ed., Ithaca, Cornell University Press, 1996.

${ }^{54}$ Id., ib.; WeINBERG, Sydney S. The World of our Mothers... Op. cit.

${ }^{55}$ WeINBERG, Sydney S. The World of our Mothers... Op. cit.
} 
Gênero em estudos comparativos de imigração

muito ligada ao seu irmão mais novo, que, ela pensava, iria salvar a família, ele iria para a faculdade e ganharia um monte de dinheiro e salvaria as duas. Nunca houve pressão alguma para que o seu irmão deixasse a escola $e$ fosse trabalhar.

Chegando em Nova York, as moças judias deparam-se com uma sociedade moderna, o trabalho nas fábricas deu-lhes uma certa independência. As ruas fervilhavam de gente que se reunia depois do trabalho; trabalhadores, homens e mulheres, encontravam-se em sindicatos, associações socialistas, comunistas $e$ anarquistas, algumas das quais judaicas, além, é claro, das atividades que realizavam nas landsmanshaften. ${ }^{56}$ As moças solteiras $e$ as mulheres casadas, acompanhadas dos filhos, costumavam freqüentar peças de teatro por preços muito baixos. Trabalhadores, homens e mulheres, freqüentavam cursos de inglês e profissionalizante. Aqueles judeus que eram religiosos reuniamse em sinagogas. Toda essa agitação da vida urbana - as cidades com as suas ruas apinhadas de gente - constituía um verdadeiro fermento para as jovens que buscavam emancipar-se das restrições do Velho Mundo.

Algumas jovens imigrantes judias já eram socialistas na Europa ou vinham de famílias socialistas. Na cidade de Nova York, encontraram grupos semelhantes e também mulheres de postura feminista, passando então a questionar as limitações impostas às mulheres. Martha fala sobre a mãe e as suas amigas:

Minha mãe, uma vez, cortou o seu cabelo, foi um grande acontecimento $e$, quando ela fumou um cigarro, foi um grande acontecimento. Havia conversa sobre amor livre, mas somente conversa. Eu não sei de pessoa alguma que tenha praticado amor livre no círculo dos meus pais Martha ri -. Mas, havia conversa e, como eu digo, a maior

${ }^{56}$ Landsmanshaft, em iídiche, associação formada por imigrantes judeus da mesma procedência. 
Ethel V. Kosminsky

revolta é que ela fumou um cigarro e, foi o fim disso. Um cigarro. E todas as mulheres, elas começaram a cortar o seu cabelo, a maioria delas usava o cabelo preso em coque. (...) Minha mãe e suas amigas gostavam muito de ir ao cinema. Elas adoravam filmes. (...) Havia um monte de conversa sobre uma porção de assuntos, sobre Emma Goldman. Emma Goldman era uma mulher ativa em prol do movimento pelo amor livre e praticante também e, também anarquista. Eu costumava ouvir sobre isso, sobre Emma Goldman. Era conversa, muita conversa.

Diversas mulheres e homens judeus parecem ter levado consigo, como parte de sua carga cultural do processo de migração, essa disponibilidade para novos valores. A sociedade judaica tradicional da Europa Oriental começou a mostrar sinais de mudança e de desintegração na terceira parte do século XIX, sob a influência da Haskala ou Iluminismo judaico. ${ }^{57}$ Os iluministas tendo descoberto o amor romântico na ficção alemã, que eles admiravam, rebelaram-se contra os casamentos tradicionalmente arranjados. A vida econômica também estava mudando. A proletarização das massas judaicas e a sua acelerada urbanização romperam com segmentos da sociedade tradicional, que ainda não haviam sido atingidos pelas idéias modernistas. Os trabalhadores se voltaram para o Bund. ${ }^{58}$ Outros, incluindo os artesãos e uma pequena classe média, se tornaram comunistas, anarquistas e sionistas de vários matizes.

\footnotetext{
${ }^{57}$ Haskala, em hebraico, ou o Iluminismo judaico, surgiu em Berlin, na então capital da Prússia, no século XVIII. O movimento pregava a completa emancipação dos judeus como cidadãos livres em relação ao estado, sem a intermediação da organização comunitária judaica, a Kehilla. Propunha também a secularização do ensino, valorizando a realização pessoal. A Haskala alcançou a Europa Oriental, onde quer que existissem trilhos de trem. DAWIDOWICZ, L. The golden tradition: jewish life and thought in eastern europe. New York, Schocken Books, 1967.

${ }^{58}$ Bund, movimento judaico operário socialista da Europa Oriental.
} 
Gênero em estudos comparativos de imigração

Aqueles que imigraram para os Estados Unidos, portando idéias modernistas, encontraram um campo fértil na cidade de Nova York. Para uma parte das mulheres imigrantes, o mundo judaico da Europa Oriental havia se tornado demasiado estreito para as suas aspirações, demonstraram então um grande interesse em participar das atividades políticas, sindicais, associativas e dos novos costumes no que diz respeito à moda, ao uso do cigarro $e$ às relações homem-mulher.

Algumas mulheres, mesmo casadas, trabalhavam. Muitas vezes o trabalho era encarado como uma "ajuda" ao marido, nas candy stores ${ }^{59}$ da família, ou retornavam às fábricas, de vez em quando, para contribuir com alguma renda extra. A mãe de Martha estava neste último caso:

Ela trabalhava em fábrica, ela era ativa, fazia greve, voltava para o trabalho e, como ela era uma costureira especializada em corpo de vestido, o trabalho era sazonal. Ela não trabalhava com regularidade. Contudo, quando ela voltava para o trabalho, sempre que ela trabalhava, ela sempre representava os trabalhadores diante do patrão. Ela não era a única a fazer isso. Deve ter havido outras mulheres que faziam a mesma coisa - Martha ri -. O seu nome não vai ficar na história. $\mathrm{E}$ o dinheiro que ela ganhava, eu descobri mais tarde, depois que ela morreu, que ela tinha a sua própria conta no banco, o que deve ter sido fora do comum para mulheres naqueles dias. Mas, ela trabalhava muito pesado e conseguiu ganhar o sustento.

As famílias que as imigrantes constituíam eram em grande parte família pequenas com poucos filhos. A regulação da fecundidade é importante em uma época em que essas medidas não eram comuns e pela "estratégia" de reduzir o número de filhos. As imigrantes justificavam essa atitude para poderem

${ }^{59}$ Candy stores, pequenas lojas que vendiam refrigerantes, cigarros, jornais e balas. 
Ethel V. Kosminsky

proporcionar uma melhor educação para os seus filhos e também pela sua atitude crítica em relação ao "mundo" em que viviam. Conta Martha:

Eu quero lhe dizer que, minha mãe não era a única que tinha filhos e trabalhava em uma oficina. A geração da minha mãe teve famílias muito pequenas. Havia muitas famílias que tinham somente um único filho. Três filhos era um bocado. Quando eu perguntei para minha mãe porque eu não tenho um irmão ou uma irmã, ela disse: 'Você quer lições de piano, você quer ir para o acampamento? Você quer ir para o shule. ${ }^{60}$ Tudo isso custa dinheiro'. Eles já tinham conhecimento sobre o controle de natalidade. Era econômico. Emma Goldman já tinha feito propaganda e eles já sabiam de Margaret Sanger. Ela era uma grande advogada do controle da natalidade. Ela não era judia. Havia muitas mulheres judias que haviam se incorporado ao controle da natalidade. Se eu não estou enganada, Emma Goldman também.

A mãe de Jô era "uma fervorosa socialista" e o pai "um fervoroso anarquista". O relato de Jô sobre os seus pais mostra o quanto eles foram inovadores:

Eu fui um bebê da menopausa. Minha mãe e meu pai se juntaram e viveram juntos sem se casar por 18 anos antes que eu nascesse. Eles não queriam ter filhos. Eles estavam envolvidos filosoficamente com a idéia de que não se deve ter filhos neste tipo de mundo. Eles tinham medo de que se eles tivessem um filho, o filho poderia ir para o exército $e$, então, eles decidiram conscientemente que não teriam filhos. Então, eu suponho, que eles constituíram um casamento consensual, o que existiu muito naqueles dias. Em algum momento, depois de viverem juntos por 18 anos, a minha mãe decidiu que ela queria ter um filho. (...) E,

${ }^{60}$ Shule, em iídiche, escola. 
Gênero em estudos comparativos de imigração

depois de 18 anos, a minha mãe ficou grávida e eu nasci. Assim eu fui criada por pais velhos. A minha mãe estava com bem mais de 40 anos e o meu pai nos seus 50 .

Martha exprime bem o pensamento da geração dos seus pais sobre a educação dos filhos:

Eles pertenciam a uma geração que acreditava em educação e não havia tal coisa como a filha não ter acesso à educação. Ela tinha que casar, mas ela tinha que ter uma educação e um emprego até ela se casar. E, mais tarde, ela poderia trabalhar. Porque pessoa alguma iria dizer para ela, você não pode trabalhar. Isso era o que tinha de ser feito no meu círculo. Eu não posso falar por todo o mundo, eu posso somente falar por um pequeno grupo. Eu tenho a impressão de que era mais do que um pequeno grupo.

A percepção de mudança já está presente na geração desses imigrantes, pelo menos em alguns dos pais das entrevistadas. Melhor dizendo, uma co-existência do novo e do velho, uma certa ambigüidade que pode ter sido uma das características desses imigrantes. No estudo sobre três mulheres judias imigrantes e os seus sindicatos, durante a primeira metade do século XX, KesslerHarris ${ }^{61}$ mostra que as mulheres, que eram ativamente engajadas nas lutas por melhores condições de trabalho na indústria de confecção, enfrentaram alguns problemas, de um lado, um movimento sindical hostil às mulheres $e$, do outro, as tradições comunitárias que desencorajavam a sua participação nesse tipo de atividade.

Essas três líderes, que tentaram organizar as suas colegas de trabalho, não eram feministas no sentido de que não colocavam os direitos sociais e políticos das mulheres em primeiro lugar.

${ }^{61}$ KESSLER-HARRIS, A. Organizing the unorganizable: three jewish women and their union. In: CANTOR, M.; LAURIE, B. (orgs.) Class, sex, and the woman worker. Westport, Greenwood Press, 1977, pp.144-165. 
Ethel V. Kosminsky

Todas afirmavam o predomínio da luta de classe e, quando havia um conflito entre a sua consciência de classe e a sua identificação como mulher, elas concordavam com a tradição, com os seus costumeiros papéis sexuais, e acatavam a posição da classe trabalhadora. ${ }^{62}$

Entre os imigrantes estudados, as relações de gênero, a partir da família em direção a outros grupos também discriminados, parecem ter sido de parceria. Um misto de Mitzvá ${ }^{63}$ com prática política, conforme apreendemos do relato de Shirley:

Nós éramos muito pobres. As inclinações políticas do meu pai eram para a esquerda e o meu tio era de ultraesquerda. O espírito da nossa casa era sempre a favor do necessitado. Isso era muito claro na minha família. Você estava sempre tentando ajudar os necessitados, as pessoas que não tinham sido bem-sucedidas, o operário, o homem pobre. Esse era o sistema de valor na nossa casa. Eles eram muito comprometidos com a igualdade entre as pessoas. Eu lembro disso na minha família. Duas coisas permaneceram na minha mente de criança: uma foi a respeito de Joe Louis, um lutador negro. Quando eu fui para a escola, estavam todos transtornados porque um afro-americano ganhou e os meus pais estavam muito felizes com isso, o que me impressionou muito. A outra coisa foi com as Testemunhas de Jeová, que tinha muitos membros negros. Eles vieram até nós, naquele tempo, estávamos vivendo em Cleveland $e$ não havia lugares onde essas pessoas negras pudessem se hospedar, os hotéis não os aceitavam, naquela época, porque eles eram negros. Alguém nos telefonou e perguntou se nós tínhamos um lugar para essas pessoas, eles ficaram por dois dias. Os meus pais então disseram sim e colocaram cobertores no chão da sala para

${ }^{62}$ ID., IB..

${ }^{63}$ Mitzvá, em hebraico, a prática com alegria de uma ação verdadeiramente virtuosa, bondosa e ética. ROSTEN, L. Treasure of Jewish Quotations. New York, McGraw-Hill, 1972, pp.696-671. 
Gênero em estudos comparativos de imigração

que eles pudessem dormir e ir para o congresso deles. Eu fiquei muito impressionada com isso. Eles moravam em uma casa, cujo proprietário ficou muito zangado de ter pessoas negras morando lá. Eles se arriscaram.

Diferente da literatura de cunho autobiográfico, escrita por Yezierka e por Cohen ${ }^{64}$, que aponta para a existência do conflito de gerações entre as tentativas de emancipação das moças e a resistência dos pais, apegados aos valores, normas e ao judaísmo ortodoxo da Europa Oriental ${ }^{65}$, os relatos das entrevistadas não se referem a esse tipo de conflito. Possivelmente porque os imigrantes, pais das entrevistadas, compartilhavam das idéias consideradas modernas, avançadas da época. Além disso, aquelas obras cobrem o período das duas primeiras décadas do século XX, enquanto que a segunda geração, desta pesquisa, atingiu os vinte anos de idade no período compreendido entre as décadas de 1940 e 1950. E os seus pais chegaram jovens e solteiros, na sua maioria, e puderam então incorporar com mais facilidade alguns dos valores e normas da sociedade norte-americana.

A maioria das entrevistadas fez curso superior, os cursos localizam-se na área de humanas, uma área desvalorizada com uma maior concentração de mulheres. Algumas fizeram também pós-graduação. Quase todas já estão aposentadas e algumas ainda continuam trabalhando. A grande maioria casou-se, e após viuvez, contraiu segundas núpcias. Outras divorciaram-se mais de uma vez.

${ }^{64}$ YeziersKa, A. Bread Givers. Op. cit.; Cohen, R. Out of the shadow... Op. cit. Esses livros foram publicados pela primeira vez em 1925 e em 1918, respectivamente.

${ }^{65}$ KOSMINSKY, E. A literatura judaico-feminina de imigração nos Estados Unidos e no Brasil. Cadernos de Língua e Literatura Hebraica, São Paulo, nº 3, 2003, pp.157-182. 
Ethel V. Kosminsky

Mães e filhas em São Paulo

Nem todas as imigrantes judias da Europa Oriental são provenientes de cidades grandes, mas para aquelas que vieram de cidades como Varsóvia, e que emigraram adultas, a cidade de São Paulo deve ter parecido bastante limitada para o exercício de atividades, tais como o trabalho, ou o simples ir e vir pelas ruas da cidade. Para a mãe de Helena, procedente da cidade de Riky, perto de Varsóvia, onde ela tinha um pequeno bazar, em que vendia linhas e agulhas, a cidade de São Paulo deve ter parecido bastante conservadora. Logo que chegou, ela foi trabalhar em uma fábrica de bolsas, no Bom Retiro, tendo, depois do casamento, aberto um bazar com o marido na José Paulino ${ }^{66}$, onde vendiam lenços, agulha, linha, entre outras mercadorias. $\mathrm{Na}$ década de 1930, eles tinham uma fábrica de roupas para crianças e ela (a mãe) trabalhava muito, ela saia de mala e vinha com o mostruário de bonde, para ir nos bairros da Penha, da Lapa, como vendedora das roupas da fábrica, para vender para as lojas. Agora o termo é representante. (...) Minha mãe então era assim uma zorra, de pegar bonde com mala, ela conta que uma vez perguntaram para ela:

- Seu marido está doente?

- Não, por quê?

- Porque a senhora está trabalhando.

- Precisa meu marido estar morrendo para eu trabalhar?

[Helena ri] Você imagina a mentalidade da época, que seu marido está morrendo ou doente para a mulher trabalhar.

A mulher na cidade de São Paulo, nos anos de 1920 e 1930, vivia limitações na sua mobilidade espacial: aquela que andasse

${ }^{66}$ Rua principal do Bom Retiro, bairro ocupado, em boa parte, por judeus. Ver KOSMINSKY, E. Os judeus no bairro do Bom Retiro... Op. cit. 
Gênero em estudos comparativos de imigração

sozinha nas ruas da cidade não era "bem vista". É o que conta Amélia:

Minha mãe era uma mulher muito bonita, vistosa e apesar dela ser de uma vilazinha [Opole], ela ia para Varsóvia, a capital da Polônia, então ela estava acostumada já naquela época a sair sozinha na rua. Ela veio para cá em 1926 e, acostumada que uma mulher saia sozinha na rua, se arrumava saia na rua, então quando ela veio para cá isso era muito normal para ela, ela sair sozinha. Depois que eu nasci, ela me contava, ela ficou muito doente e tinha um médico que era na cidade, na rua João Brícola, me lembro até hoje, Dr. Braga. Então, naquela época, ela se arrumava, punha o chapéu, luvas, saía toda bonita (do Bom Retiro), e ela era mal falada pelos goim [não-judeus], como que uma mulher toma um bonde sozinha, e vai para a cidade sozinha.

Eh, nossa! Durante anos, aqui o pessoal era muito provinciano, mas muito provinciano. Quando nós mudamos para o Cambuci, eu devia ter uns seis, sete anos, olha, mas eram tão provincianas! A minha mãe naquela época também se arrumava, já não com chapéu, tudo, mas ela tomava o bonde, ela vinha para o Bom Retiro encontrar as amigas, olhavam para ela como se fosse uma prostituta. Como uma mulher sai sozinha de casa? Elas não saiam de casa $e$ quando a minha mãe conversava com elas, elas falavam assim: "D. Sara, o meu marido é tão bom, ele não me bate". É isso. Essas mulheres eram brasileiras, filhas de italianos, filhas de brasileiros, de segunda geração, mas, era gente muito provinciana. $\mathrm{O}$ pessoal mais grã-fino, vamos dizer, mais rico, que viajava para a Europa, tinha outro conhecimento, mas aqui, o brasileiro era demais, mesmo aqui na cidade de São Paulo. Na Europa, a mulher se porta de uma maneira diferente como, de sair sozinha, de uma mulher ler, escrever, saber as coisas, mas o pessoal que não era assim, de uma classe alta mesmo, era muito provinciano, era uma província mesmo São Paulo. 
As moças das famílias da elite cafeicultora paulista, recebiam uma educação à francesa e costumavam viajar para Paris, o que lhes poderia, talvez, dar uma maior independência. ${ }^{67}$ Mesmo assim, nas três primeiras décadas do século XX, poucas moças das camadas médias e altas, as chamadas moças de "boa família", ousavam sair sozinhas nas ruas da cidade. As mulheres casadas não poderiam sair à rua, acompanhadas de um homem que não fosse o marido ou parente próximo. ${ }^{68}$ Dependendo da idade com que vieram para o Brasil, do seu modo de vida e da sua experiência anteriores à imigração e do local de procedência, essas mulheres estranharam as condições de vida $e$ a posição social da mulher na cidade de São Paulo, principalmente aquelas que traziam uma postura inovadora em relação aos parâmetros da sociedade brasileira. Nem todas as mulheres imigrantes, porém, trabalhavam fora ou saiam de casa sozinhas. Muitas realizavam as tarefas domésticas, cuidavam dos filhos e "ajudavam" o marido em serviços que eram executados em casa. Esse é o caso da mãe de Hana, que costurava em casa, fazendo consertos em ternos que o pai trazia:

Às vezes, também como parte do sustento, ele [o pai] trazia terno de pessoas que usavam, às vezes, terno de linho $e$ gastava muito a gola. A minha mãe, que sabia costurar, com muito capricho tirava da lapela do terno um pedaço de tecido e fazia uma nova gola no terno. E era uma coisa que devia ser medida milimetricamente porque não havia bastante tecido e, se você errasse, estragava a gola e ela fazia isso em casa quando aparecia uma oportunidade de ajudar com alguma coisa mais.

\footnotetext{
${ }^{67}$ Esse foi o caso da pintora Tarsila do Amaral, uma mulher considerada emancipada, à frente do seu tempo, e dona de um notável cabedal econômico e social. TutToilmondo, J. São Paulo, de Tarsila do Amaral. Nossa História, Rio de Janeiro, ano 1, n 3, jan. 2004, pp.40-44.

${ }^{68}$ Maluf, M.; MotT, M.L. Recônditos do mundo feminino. In: SevcenKo, N. História da vida privada no Brasil. São Paulo, Cia das Letras, 2002, vol. 3, pp.368-421.
} 
Gênero em estudos comparativos de imigração

Essa ajuda não era considerada trabalho. Este era visto então como a atividade remunerada executada fora de casa, pelo homem, o chefe da família. Essa diferença de percepção entre o trabalho e como este é visto tem raízes na falta de congruência entre valores e experiência, quando o background cultural desempenha um papel influenciando as escolhas de trabalho e determinando também o que as experiências de trabalho significam para os imigrantes. ${ }^{69}$ Esses valores patriarcais encontraram um ambiente apropriado para o seu desenvolvimento na sociedade brasileira.

O serviço doméstico e mais o cuidado com os filhos absorviam a vida diária da mulher imigrante. É o que se depreende da fala de Hana:

Não, nunca tinha faxineira, alguma época tinha lavadeira como era habitual naquela época. A mãe não tinha nenhuma ajuda, éramos seis pessoas. A avó não fazia o serviço da casa. Era uma senhora de idade, muito gorda, ela só fazia doces, de vez em quando. Ela fazia doces, quando acho que ela tinha insônia e, depois, acho que ela acordava a minha mãe para cuidar do forno. Então, minha mãe ficava "p" da vida, ela acabava de fazer os doces, ia dormir e minha mãe tinha que ficar tirando e pondo os tabuleiros no forno com os doces. Nós ajudávamos muito pouco, muito pouco porque todo mundo tinha três, quatro escolas. E minha mãe levava também enquanto foi preciso, levava. Lógico até uns 10, 11 anos, ela levava e buscava.

O fato da mulher imigrante se dedicar aos cuidados da casa $e$ dos filhos poderia implicar, aparentemente, em uma vida reclusa. No entanto, pode ser que essa não tenha sido a norma. A preocupação das mulheres imigrantes com o casamento das filhas e dos filhos dentro do grupo étnico levava-as a freqüentarem

${ }^{69}$ YANS-MCLAUGHLIN, V. Italian women and work: experience and perception. In: CAntor, M.; Laurie, B. (orgs.) Class, sex, and the woman worker. Op. cit., pp.101-119. 
Ethel V. Kosminsky

o Círculo Israelita, que era mais feito para a juventude, para se encontrar para casar mesmo, as mães iam juntas, ficavam sentadas lá naquelas cadeiras, os rapazes tiravam para dançar, se dançava, se conheciam, casavam [conta Amélia].

Algumas mulheres participavam de associações comunitárias judaicas e ajudavam os próprios conterrâneos, desse modo fortalecendo os laços entre os imigrantes e as famílias que ficaram, e facilitando de certa forma o processo de adaptação de sua família e dos seus Landsman (conterrâneos) à vida na nova sociedade. Participavam assim de uma espécie de rede étnica de ajuda mútua, compartilhando de valores comuns e incorporando alguns dos novos. ${ }^{70}$

Amélia se recorda da ajuda prestada pela sua mãe a outras mulheres também imigrantes:

Eu lembro minha mãe, ela escrevia, lia e muitas vinham na casa dela para ela escrever cartas, meu pai e minha mãe já eram cultos por eles mesmos, autodidatas, mas eram. Mas, vinham amigas, vizinhas, antes da guerra, elas falavam o que queriam e ela escrevia cartas para Europa, para os parentes delas. Quando chegavam as cartas, minha mãe lia as cartas para elas.

As mulheres imigrantes estabeleceram contatos de vizinhança com judeus e não judeus $e$, em alguns casos, com mulheres das camadas mais baixas que prestavam serviços domésticos, tais como, lavadeira e faxineira. Esses contatos implicavam em uma certa aproximação com pessoas de outras etnias. Essa aproximação pode ser explicada pela diversidade étnica e de classe existente então nos bairros da cidade. São Paulo ${ }^{70}$ SOYER, D. Jewish Immigrant Associations and American Identity in New York,
1880-1939. Cambridge, Harvard University Press, 1997. 
Gênero em estudos comparativos de imigração

ainda não havia se tornado uma cidade tão segregada, como viria a ser. $^{71}$

Hana lembra-se dos vizinhos italianos no bairro da Bela Vista, que mandavam um doce italiano na época do Natal e das mulheres negras com as suas roupas de tafetá. E da D. Maria, uma negra "sempre com pano na cabeça, que vinha lavar roupa na minha casa, lavadeira, era um tanque cheio no dia de lavar lençóis". A grande desigualdade entre as classes sociais possibilitava a algumas famílias de imigrantes judeus, apesar da pobreza $^{72}$, ter a seu serviço pessoas mais pobres ainda. Se isso se constitui em um privilégio de classe, do outro lado, permite a aproximação entre pessoas de origem social e étnica diferentes.

Além de ajudar os filhos e os netos a fazerem os deveres de casa, a mãe de Hana dizia para a sua faxineira, mãe de seis filhos,

manda ele aqui que eu ajudo ele a fazer a lição de casa (...). Acho que dos seis filhos que ela teve, quatro passaram pela mão da minha mãe e desses quatro, o mais velho depois se formou em faculdade e veio trazer o primeiro convite de formatura da faculdade para a minha mãe porque sem a minha mãe ele não teria chegado à faculdade.

Nessa solidariedade para com os mais pobres, está implícita a prática da Mitzvá, mas diferente dos Estados Unidos, não há uma conotação política expressa de desafio ao status quo, e sim, uma conciliação entre grupos, que se aproxima da troca de favores entre os desiguais, uma das características da sociedade brasileira. ${ }^{73}$

\footnotetext{
${ }^{71}$ KosminSKY, E. Os judeus no bairro do Bom Retiro... Op. cit.

72 ID., IB.

${ }^{73}$ DA MATTA, R. Digressão: a fábula das três raças, ou o problema do racismo à brasileira. In: Relativizando: uma introdução à antropologia social. $4^{\mathrm{a}}$ ed., Petrópolis, Vozes, 1984, pp.58-85.
} 
Ethel V. Kosminsky

\section{As relações de gênero entre pais imigrantes e filhas brasileiras e norte- americanas}

As diferenças entre as duas sociedades receptoras evidenciam-se na questão do trabalho. Para as moças imigrantes judias, em São Paulo, o trabalho não era bem visto. Conta Hana que a sua mãe e as irmãs desta "não chegaram a trabalhar enquanto solteiras. Cada uma das tias foi chegando (no Rio de Janeiro) e vivendo na casa de alguma tia, até que pudesse se ajeitar, mas não trabalharam. Minha mãe nunca trabalhou fora de casa, duas de suas irmãs trabalharam, fora de casa, depois de casadas com os maridos, até se aposentarem".

Essa questão da moça não trabalhar fora de casa remonta à vida na Europa Oriental e à estratificação social da época. É o que Hana comenta a respeito da família materna, antes da emigração:

Uma moça solteira para sair para trabalhar, eu penso que não era aquela coisa mais apreciada na minha família por questão de Yikhes. ${ }^{74}$ Eram todos realmente muito remediados $^{75}$, eu não saberia nem classificar economicamente, mas nenhuma delas, inclusive as tias da minha mãe, que eram jovens, também não saiam para nenhum tipo de trabalho. Então se contava de alguém, fulana saiu para trabalhar de costureira numa fábrica, viajou para Czernovitz, que era a cidade maior da região (da Romênia), para trabalhar numa fábrica com costura, o que era uma colocação no Yikhes numa categoria social

\footnotetext{
${ }^{74}$ Yikhes em iídiche, do hebraico Yihus, linhagem, ancestral. Prestígio familiar obtido através da virtude, do conhecimento, das boas ações, da caridade. ROSTEn, L. Treasure of Jewish Quotations. Op. cit., p.696.

${ }^{75}$ Os imigrantes judeus da Europa Oriental procedem de cidades grandes como Varsóvia, Odessa e outras, de cidades pequenas e vilas; da mesma forma são oriundos de famílias com mais ou menos recursos ou de famílias muito pobres. No entanto, é o mercado de trabalho de ambas as sociedades, a brasileira e a norte-americana, que vai nortear a inserção ocupacional desses imigrantes aliado à carga cultural, entendida como a sua origem e experiência de vida urbana. KOSMINSKY, E. A presença da Europa.... Op.cit.
} 
Gênero em estudos comparativos de imigração

mais baixa, então, procurava-se não chegar a isso $e$ procurava-se sempre gente de nível cultural mais elevado para que houvesse uma ascensão.

Essa postura das famílias, quer "remediadas" ou não, de recusa do trabalho feminino - antes do casamento, e o fato de ser visto como "ajuda", após o casamento, desde que desempenhado no espaço controlado pelo marido - é re-atualizada no Brasil. Diferentemente dos Estados Unidos, os imigrantes têm uma rápida ascensão social no Brasil, constituindo-se em membros das camadas médias da população. Passaram então a adotar os valores dessas em relação às suas filhas solteiras. Dessa forma, mulheres com vivência do novo não chegaram a participar diretamente do mercado de trabalho a não ser através do marido. Além disso, embora a cidade de São Paulo se encontrasse em pleno processo de industrialização, o mercado de trabalho ainda era reduzido para as camadas de colarinho branco.

Para as moças judias imigrantes, na cidade de Nova York, o trabalho se colocava como um imperativo para a própria sobrevivência e da família, significando também a aquisição de uma certa independência e de uma melhor posição na família.

A mãe de Shirley chegou em Nova York, sozinha, com 13 anos de idade e foi morar com a irmã em Philadelphia:

Eles queriam que ela fosse para a escola e ela foi para o ensino fundamental mas ela se sentiu muito mal porque ela era alta e tinha 13 anos de idade e assim, um dia, ela se recusou a ir para a escola. Ela foi para as fábricas, ela devia ter 14 anos e não estava se dando bem com a sua irmã. Quando ela tinha 16 anos, ela veio para Nova York, ela tinha um primo que trabalhava em uma fábrica de gravatas, então ela trabalhou por um número de anos até que ela encontrou meu pai quando ela tinha 19 anos. Ele estava trabalhando em uma oficina na Broadway, em Nova York, e então eles casaram. 
Ethel V. Kosminsky

A mãe de Roberta chegou em Nova York com 10 anos de idade, com a mãe e dois irmãos, por volta de 1905:

Ela foi para a escola por apenas dois anos. Ela deve ter estudado até a $6^{\text {a }}$ série (do ensino fundamental). Ela trabalhou com a sua mãe, em casa, fazendo perucas. Posteriormente, ela deve ter tido acesso a alguma educação porque ela se tornou contadora. Assim ela deve ter tido algum preparo formal em contabilidade, mas eu não sei como ela mesma conseguiu isso.

Dessa forma, na cidade de Nova York, não se cogitava que uma moça imigrante ficasse sem trabalhar, ela não somente tinha que manter a si própria como contribuir para a manutenção da sua família.

Se de um lado, na cidade de São Paulo, pode ter havido um reforço dos padrões tradicionais, como na questão do trabalho para a moça imigrante, também ocorreu um conflito de gerações entre as filhas nascidas naquela cidade e os seus pais, ou seja, o poder paterno representando o Velho Mundo, $e$ as filhas significando uma sociedade que poderíamos dizer em transição, isto é, tradicional em vias de modernização. ${ }^{76} \mathrm{~A}$ necessidade de mudança de um ambiente cultural para outro causa a sensação de encontrar-se fora do lugar, de sentir-se dividida, fragmentada, provocando alguns conflitos, não somente para as mulheres imigrantes judias do começo do século XX, mas também para as suas descendentes. ${ }^{77}$

76 "O que é típico na transição, a coexistência de formas sociais que pertencem a épocas diferentes, imprime um caráter particularmente conflitivo ao processo, que é inevitavelmente vivido como crise, porquanto implica uma contínua ruptura com o passado, que não só tende a dividir pessoas e grupos como penetra na consciência individual, em que também chegam a coexistir atitudes, idéias, valores, pertencentes a diferentes etapas da transição". GERMANI, G. Análise da transição. In: Costa PINTO, L. A.; BAzzAnella, W. (orgs.) Teoria do desenvolvimento. Rio de Janeiro, Zahar, 1967, p.125.

${ }^{77}$ ANTLER, J. The journey home... Op.cit., grifo nosso. 
Gênero em estudos comparativos de imigração

Esses conflitos aparecem relacionados às aspirações das jovens, filhas de imigrantes, em dar continuidade aos seus estudos $e$, em alguns casos, em trabalhar. Célia fala da resistência do pai:

Aí apresentou-se um pequeno drama porque eu queria fazer faculdade. Minha mãe não dizia nada, coitada (...). Quanto mais você estuda, ele dizia para mim, menos possibilidade de achar um marido, vai ficar dona sabichona, ele falava. Então eu fiz o curso de secretariado.

Essa situação enfrentada por Célia diferia daquela vivida pela sua irmã mais velha que somente pensava em casar-se, o que ela realmente fez, aos 18 anos de idade, casando-se com um parente afastado da família. O seu irmão, pelo fato de ser homem, ocupava uma posição privilegiada na família, como bem coloca Célia:

Meu irmão, onde o judeu põe todas as esperanças, era um rapaz bonito, mas folgadão que não estava nem ai. Ele militava no Paulistano, ele nadava, ele não sei o quê, de estudar, nada! E a única que estudava era eu, coitada, só que não tinha chance. (...) Aí o tempo foi passando, eu arranjei um trabalho para grande desgosto dele. Eu já tinha 26 anos e ele se arrancava os cabelos. Essa solteirona aqui, o que pretende e, bom, até que chegou o dia que eu conheci o que foi o meu marido.

No caso dos pais de Helena, o seu pai também se manifestou contra a continuidade dos seus estudos, no entanto, ela encontrou uma forte aliada na sua mãe, como ela relata:

Fiz matemática, matemática que sempre foi a minha paixão. E... uma coisa interessante sobre os imigrantes é que meu pai, quando eu tinha 18 anos, 19, ele achava que eu não devia fazer a faculdade. Meu pai dizia que não precisa estudar, minha mãe: 'O quê!? Se a Helena, a Heleninha quer estudar, como?' Porque meu pai não 
Ethel V. Kosminsky

queria, ele era um pouco seguro, vai ter que pagar cursinho, mas minha mãe falou, está falado, aí eu fui fazer cursinho. (...) ai eu fiz o cursinho, entrei na faculdade, claro que terminei, fiz os quatro anos. Porque ele achava que eu devia casar (...).

Essa atitude dos pais correspondia aos valores dominantes naquela época, na sociedade brasileira, como diz Hana:

(...) nem todos faziam faculdade, moças muito menos, tanto que eu não fui fazer faculdade logo depois da contabilidade porque eu trabalhava. Das minhas colegas de colégio, ninguém acho que foi fazer faculdade, algumas não iam fazer nem o colegial, nem contabilidade, oito anos já era suficiente para uma moça judia. Mais tarde, eu fui fazer faculdade, eu posso dizer que eu tive apoio, minha mãe foi ver o resultado do vestibular e telefonou para mim no escritório que eu tinha passado no vestibular.

Alguns pais, porém, tinham o ponto de vista contrário, desejavam que as filhas fizessem faculdade, o que nem sempre era acatado. É o que relata Amélia, que fez o curso de secretariado na Álvares Penteado:

Infelizmente não cheguei a fazer faculdade. O meu pai ficou muito triste porque ele disse que, se ele não tinha tido essa oportunidade, que na Polônia nem escola ele pode fazer, ele queria muito que eu fizesse, mas infelizmente a gente quando é criança vai mais atrás da cabeça dos outros.

Em relação às filhas terem acesso ao curso superior, os dois grupos de imigrantes, provenientes da Europa Oriental, apresentaram diferenças de opinião. A maioria daqueles que se fixaram nos Estados Unidos foram favoráveis, enquanto que no Brasil, foi o contrário.

Assim, nos Estados Unidos, na cidade de Nova York, conta Jô que, apesar da pobreza em que viviam, 
Gênero em estudos comparativos de imigração

\begin{abstract}
eu tive tanto porque todo o ethos de ser judeu e a batalha por educação eram tão importante, mais importante para a minha mãe do que para o meu pai, por ser anarquista, ele estava ocupado em refazer o mundo. Eu tinha aulas de dança, lições de música, lições de locução e eu ia para o ballet, para a ópera, o teatro. A minha mãe me arrastava para todo o lugar com pouquíssimo dinheiro. Assim, por um lado, éramos muito pobres, era uma luta e, por outro lado, eu era muito rica, crescendo muito rica - sempre a ênfase em aprender, e ler, estudar.
\end{abstract}

Provavelmente, no Brasil, a sociedade receptora impôs as suas normas e valores em relação à educação das moças. Além disso, as histórias de vida desses imigrantes, nos Estados Unidos, devido à técnica da bola de neve, guardam uma semelhança entre si, foram quase todos "intelectuais-trabalhadores", segundo uma das filhas.

No Brasil, as histórias de vida dos imigrantes foram diferentes, a ascensão social $e$ a incorporação dos valores das camadas médias ocorreram de forma mais rápida. O grupo de imigrantes selecionado, a partir de vários contatos sociais, apresenta uma menor homogeneidade entre si, quanto à sua vivência no Brasil, isto é, encontramos desde aqueles que se tornaram proprietários de empresas a aqueles que, embora pertencentes às camadas médias em termos de visão de mundo $e$ de valores, dispunham de menos recursos.

Os conflitos entre pais e filhas apareceram também em relação à obrigatoriedade do casamento. A necessidade do casamento, que faz parte da tradição judaica, encontrou na sociedade brasileira, marcada por relações patriarcais, um ambiente propício, uma vez que as mulheres dificilmente atingiriam uma posição de respeito se não fossem casadas. Assim, elas teriam que casar jovens, daí as brigas de Célia com o pai, que não aceitava o seu desejo de estudar e trabalhar: "A função da mulher é achar um marido e casar ponto". 
Mas, a questão não era somente "achar um marido". A escolha do futuro cônjuge tinha por base o Ykhes. No Brasil, esse atributo de valor foi re-atualizado, passando a se referir àqueles que tivessem educação superior, que não exercessem atividades manuais, que dispusessem de bens, enfim que fossem de "boa família". Essa questão do dinheiro podia ou não pesar na escolha. Hana especificou como o termo linhagem (Ykhes) era definido no Velho Mundo: "Era pela cultura, sim, uma pessoa sem cultura podia ir trabalhar de operário, e outro ia trabalhar eventualmente de professor". No Brasil, o Ykhes foi cultuado lado a lado com o estudar, como diz Hana: "Estudar realmente era a preocupação, não importava que não havia dinheiro". A aceitação do pedido de casamento estava condicionado a esse atributo, como conta Hana: "A questão do Ykhes, da estirpe, era muito marcado, se não tivesse um Ykhes, o cara poderia quase morrer de fome, mas se não tivesse Ykhes, não passava, não ficava membro da família".

No entanto, à medida em que a riqueza se tornava um critério de status muito importante, esse dado passou a pesar na escolha tanto do noivo quanto da noiva. Amélia se recorda que, quando entrou na casa dos seus futuros sogros, no começo do namoro, há 50 anos, não foi "muito bem recebida". Ela explica a diferença:

Minha sogra tinha cozinheira, tinha tapetes persas, (...) era uma vida muito diferente dos meus pais, o meu pai podia ser culto, podia ser maravilhoso e minha mãe tudo, mas era uma outra classe social.

As filhas dos imigrantes, naquela época, ocupavam posições na hierarquia do trabalho, ditas femininas, isto é, eram secretárias, trabalhando em escritórios com datilografia e contabilidade. As que fizeram faculdade passaram a exercer o magistério, a enfermagem. Nenhuma médica ou advogada. Algumas que se casaram, abandonaram o trabalho passando a viver uma 
Gênero em estudos comparativos de imigração

existência doméstica de classe média. Outras não se casaram, passando a se dedicar totalmente ao trabalho e à família (pais, irmãos, sobrinhos).

Na cidade de Nova York, as filhas dos imigrantes também exerceram ocupações chamadas femininas, trabalhando como professora, assistente social, bibliotecária, auxiliar de administração. Duas das entrevistadas, no entanto, exerceram cargos de chefia, uma em órgão público e a outra em privado. Quase todas, com exceção de uma, se casaram, não tendo sido mencionada, durante as entrevistas, qualquer referência à escolha do cônjuge ter sido baseada em Ykhes. Entre todas as que casaram, uma encontrava-se divorciada do seu segundo marido. Duas casaram-se em segundas núpcias, em razão da viuvez, com homens católicos de origem irlandesa. O primeiro casamento de todas as entrevistadas foi com homens judeus. A senhora divorciada não esclareceu qual a identidade étnica do seu segundo marido. No Brasil, aquelas que se casaram, o fizeram dentro da comunidade judaica, indicando, talvez, por parte da geração de brasileiras, uma maior preocupação com a manutenção da identidade étnica judaica através do casamento endogâmico, ou uma menor flexibilidade na escolha do parceiro, presas que ainda se encontravam aos valores ditados pelo $Y k$ hes.

\section{Conclusões}

A situação enfrentada pelas mulheres imigrantes e suas filhas era muito diferente de uma cidade para outra - sociedades e culturas muito diferentes - quanto à questão da vida em família, do trabalho, do estudo, da participação em associações $e$ sindicatos. O processo de modernização, na cidade de Nova York, enfrentado pelas imigrantes e suas filhas nascidas no Novo Mundo implicava em uma tensão: de um lado, a independência advinda do trabalho e da participação política, e do outro lado, as aspirações pelo casamento, pelo papel da esposa moderna, companheira e dona-de-casa. Esse amor romântico veio substituir 
os casamentos arranjados tendo por base o Yikhes. Esses dois papéis - o da mulher independente e o da mulher dependente se complementavam e, ao mesmo tempo, existia uma tensão entre eles, que transparecia pelas idas e vindas da mulher no mercado de trabalho $e$ nas atividades políticas. ${ }^{78}$

$\mathrm{Na}$ cidade de São Paulo, as imigrantes e suas filhas enfrentavam uma sociedade em transição, havendo uma tendência ao fortalecimento dos padrões tradicionais no que diz respeito à família, ao trabalho $e$ ao estudo, à própria mobilidade na cidade, ao fortalecimento do Yikhes como padrão regulador das atividades de trabalho e de casamento; e, ao mesmo tempo, o surgimento de mudanças a partir do questionamento de algumas filhas, quanto ao prosseguimento dos estudos, da ida ao mercado de trabalho e da não aceitação da imposição do casamento.

A importância da família e dos laços entre pais e filhos, um dos valores trazidos pelos imigrantes, sofre estremecimentos na cidade de Nova York. O stress enfrentado pelo imigrante acarreta, algumas vezes, o abandono da família, a preocupação com a realização pessoal, que desponta na segunda geração, o predomínio dos contatos secundários em detrimento dos primários - todos esses elementos acabam por diminuir o peso da família e das relações entre pais e filhos.

Na cidade de São Paulo, uma metrópole industrializada, que ainda vê o mundo através de relações pessoais e das redes de parentesco, a importância da família e das redes de parentesco, incluindo a relação pais e filhos, tende a persistir. Os valores tradicionais - casar, ter filhos, ajudar os pais - permanecem.

Comparando a adaptação dos dois grupos de imigrantes em ambos os países, nota-se que as mulheres que imigraram para os Estados Unidos atingiram um grau maior de autonomia e de independência nas relações de gênero na casa, no trabalho e na rua. Isso pode ter ocorrido pela incorporação de valores que comporiam "a mulher moderna" entre aquelas que já emigraram

${ }^{78}$ GLENN, S. Daughters of the Shtetl... Op. cit.. 
Gênero em estudos comparativos de imigração

portando "idéias avançadas" para a época. As mulheres que imigraram para o Brasil, dependendo da sua cidade de origem, enfrentaram um retrocesso, passando a uma vida mais limitada em termos de locomoção na cidade. As relações de gênero de uma sociedade em fase de transição, com aspectos marcadamente tradicionais, pautaram relações conservadoras na casa, no trabalho - no caso daquelas que trabalharam -, e na rua. Mesmo assim, algumas ousaram desafiar os conservadores pela sua prática inovadora.

Observa-se uma semelhança entre as mulheres da segunda geração nos dois países: entre aquelas que tiveram acesso ao ensino superior nenhuma seguiu um curso que resultasse em uma carreira de prestígio, como Medicina ou Direito. Na época, poucas mulheres ingressavam nesses cursos e nessas profissões consideradas de domínio masculino. Nota-se uma grande diferença entre os dois grupos no que diz respeito às relações de gênero no namoro e no casamento: as mulheres norte-americanas apresentavam mais independência, autonomia e flexibilidade na escolha dos seus parceiros do que as brasileiras. Talvez por essa razão, puderam casar, divorciar e casar-se novamente. Nem todas as brasileiras se casaram, presas, talvez, aos critérios do Yhkes, se é que casar é um dos componentes da sociedade moderna. Talvez, não. O que seria moderno é essa flexibilidade das mulheres de fazerem e refazerem uniões. 